\title{
A systematic review and meta-analysis of non-workplace interventions to reduce time spent sedentary in adults
}

\author{
Jessica Faye Hall ${ }^{1}$, Rekesh Corepal ${ }^{1}$, Thomas F Crocker ${ }^{1}$, Natalie Lam ${ }^{1}$, Louisa-Jane \\ Burton $^{1}$, Karen Birch ${ }^{2}$, Gill Carter ${ }^{1}$, David J Clarke ${ }^{1,3}$, Coralie English $^{4}$, Amanda J Farrin $^{5}$, \\ Claire Fitzsimons ${ }^{6}$, Jennifer Hall ${ }^{1}$, Ivana Holloway ${ }^{5}$, Seline Ozer $^{1}$, Rebecca Lawton ${ }^{7}$, Gillian \\ Mead $^{8}$, Sarah Morton $^{9}$, Anita Patel ${ }^{10}$, Anne Forster $^{1,3}$
}

${ }^{1}$ Academic Unit for Ageing and Stroke Research, Bradford Institute for Health Research, Bradford Royal Infirmary, Bradford, United Kingdom

${ }^{2}$ Garstang 5.76, Faculty of Biological Sciences, University of Leeds, Leeds, United Kingdom

${ }^{3}$ Academic Unit for Ageing and Stroke Research, University of Leeds, Leeds

${ }^{4}$ Physiotherapy Program, School of Health Sciences, Faculty of Health and Medicine, The University of Newcastle, Australia

${ }^{5}$ Leeds Institute of Clinical Trials Research, University of Leeds, Leeds, United Kingdom

${ }^{6}$ Institute for Sport, Physical Education and Health, The University of Edinburgh, Edinburgh, United Kingdom

${ }^{7}$ Yorkshire Quality and Safety, Bradford Institute for Health Research, Bradford Royal Infirmary, Bradford, United Kingdom

${ }^{8}$ Geriatric Medicine, Division of Health Sciences, University of Edinburgh, United Kingdom

${ }^{9}$ Centre for Clinical Brain Sciences, University of Edinburgh, United Kingdom

${ }^{10}$ Anita Patel Consulting Limited, London, United Kingdom 
medRxiv preprint doi: https://doi.org/10.1101/2021.05.27.21256673; this version posted May 29, 2021. The copyright holder for this preprint (which was not certified by peer review) is the author/funder, who has granted medRxiv a license to display the preprint in perpetuity.

It is made available under a CC-BY-NC-ND 4.0 International license .

\section{Abstract}

\section{Background:}

Sedentary behaviour has been the focus of considerable clinical, policy and research interest due to its detrimental effects on health and wellbeing. This systematic review aims to (1) develop a more precise description of different categories of interventions that aim to reduce sedentary time in adults by identifying specific components that form an intervention; (2) explore the effect of different categories of interventions in reducing time spent sedentary in adults.

\section{Methods:}

Ten electronic databases, websites of relevant organisations (e.g. the Sedentary Behaviour Research Network), and relevant reviews were searched. Inclusion criteria: Randomised controlled trials (RCTs), including cluster and randomised cross-over trials, in the adult population (clinical and non-clinical). Any study including a measure of sedentary behaviour was included even if reducing sedentary behaviour was not the primary aim. Exclusion criteria: Interventions delivered in schools, colleges, or workplaces; studies investigating the immediate effects of breaking up sitting time as part of a supervised (usually laboratorybased) intervention. Two review authors conducted data extraction and quality assessment (GRADE approach).

\section{Results:}

Searches identified 39,223 records, of which 85 studies met the inclusion criteria and were included in the review. Interventions shown to significantly reduce time spent sedentary were those which incorporated the provision of information, education, or support (advice/recommendations), in conjunction with either counselling (mean difference: -52.24 minutes/day; $95 \% \mathrm{Cl}:-85.37$ to -19.10 ) or a form of structured/prescribed physical activity (standardised mean difference: $-0.15 ; 95 \% \mathrm{Cl}:-0.23$ to -0.07 ). However, this positive effect was not maintained at follow-up. No interventions were shown to break up prolonged sitting.

\section{Conclusions:}


medRxiv preprint doi: https://doi.org/10.1101/2021.05.27.21256673; this version posted May 29, 2021. The copyright holder for this preprint (which was not certified by peer review) is the author/funder, who has granted medRxiv a license to display the preprint in perpetuity. It is made available under a CC-BY-NC-ND 4.0 International license.

This review presents a novel way of categorising interventions according to the types of components they comprised. There is evidence that interventions might be effective in reducing time spent sedentary immediately post-intervention. There were limited studies measuring sustained behaviour change.

\section{Keywords}

Systematic review; Meta-analysis; Sedentary Behaviour 
medRxiv preprint doi: https://doi.org/10.1101/2021.05.27.21256673; this version posted May 29, 2021. The copyright holder for this preprint (which was not certified by peer review) is the author/funder, who has granted medRxiv a license to display the preprint in perpetuity.

It is made available under a CC-BY-NC-ND 4.0 International license .

\section{Background:}

Sedentary behaviour, defined as any waking behaviour characterised by low energy expenditure $\leq 1.5$ Metabolic Equivalents (METs) while in a sitting, lying or reclining posture (1), is the focus of considerable clinical, policy and research interest due to its detrimental effects on health, wellbeing and economic burden (2-5). There is evidence for the negative impacts of sedentary behaviour on many health parameters $(4,6,7)$, including reduced physical function $(8,9)$, increased symptoms of depression (10) and anxiety (11), and increased risk of cardiovascular disease $(12,13)$ and premature mortality $(14-17)$.

Recent estimates suggest that adults spend a large proportion of their day in sedentary behaviours. One review found that the median self-report of daily sitting time was 5.5 hours per day (range from 3.8 hours per day to 7.6 hours per day), and was even higher (median 8.2 hours per day; range from 4.9 to 11.9 hours per day) when looking at studies that measured with devices (18).

Earlier research reported that the negative effects of sedentary behaviour are independent of the level of daily moderate to vigorous physical activity (MVPA) undertaken $(1,19,20)$. However, a meta-analysis conducted by Ekelund et al. (21) suggested very high levels of MVPA (approximately 60 to 75 minutes per day) may eliminate the increased risk of early death associated with long periods of sitting time ( $>8$ hours per day). Globally, however, only $27.5 \%$ people undertake the current recommended levels of physical activity ( $>150$ minutes per week of moderate physical activity or $>75$ minutes vigorous physical activity per week, or an equivalent combination of the two) (22). Therefore, it might be more feasible for the majority of the population to reduce sedentary behaviour than to increase physical activity to levels which might attenuate the effects of sedentary behaviour. 
medRxiv preprint doi: https://doi.org/10.1101/2021.05.27.21256673; this version posted May 29, 2021. The copyright holder for this preprint

Previous reviews have identified some types of interventions which have successfully reduced sedentary behaviour (23-27). In the systematic review and meta-analysis by Prince et al. (23), interventions focusing on sedentary behaviour were found to be more effective at reducing sedentary behaviour than interventions aimed at reducing sedentary behaviour in conjunction with increasing physical activity, or interventions focused on increasing physical activity only. In Shrestha et al's. (28) systematic review and meta-analysis, interventions targeting specific sedentary behaviours, such as leisure sitting time and TV viewing, were shown to be effective. However, Shrestha and colleagues could not conclude which type of interventions among educational, multi-component, TV-restricting, and workplace were the most effective due to the heterogeneity of interventions tested and low number of studies of each intervention type.

Martin et al. (24) recommended more precise descriptions of interventions in future systematic reviews, to identify potential single or multiple component interventions to reduce sedentary behaviour. Subsequent reviews have gone some way towards categorising interventions; however have either tended to use quite broad categories (e.g. adult or children interventions, lifestyle interventions, and behavioural or environmental interventions) (28-30) or have focussed only on behaviour change techniques and functions used (25). No systematic reviews have yet performed meta-analyses of studies according to their key intervention components (including the specific combinations of multiple components), to identify which are more effective for reducing sedentary behaviour in adults.

To address this gap, this systematic review and meta-analysis provides an updated and rigorous review of randomised controlled trials in adults, with the aim to:

- Develop a more precise description of different categories of interventions to reduce time spent sedentary by identifying specific components (and combinations of components) that form an intervention; 
medRxiv preprint doi: https://doi.org/10.1101/2021.05.27.21256673; this version posted May 29, 2021. The copyright holder for this preprint (which was not certified by peer review) is the author/funder, who has granted medRxiv a license to display the preprint in perpetuity.

It is made available under a CC-BY-NC-ND 4.0 International license .

- Explore the effect of these different categories of interventions in reducing time spent sedentary (which includes number of breaks in sedentary behaviour) when compared to no treatment, usual care, attention controls, and alternative treatments.

This review is designed to offer guidance for use in the development of future interventions aimed at reducing sedentary behaviour by highlighting the intervention components, and possible combinations of components that are effective in reducing sedentary behaviour in adults. In particular, the review will contribute to a National Institute for Health Research programme grant for the development and evaluation of strategies to reduce sedentary behaviour in patients after stroke. Taking into account the fact that the majority of strokes occur in adults aged 65 years and over (31), interventions that take place in schools, colleges, universities and workplaces were excluded from the review as they are less applicable to our population of interest.

\section{Methods}

\section{Protocol and registration}

Reporting of the systematic review is guided by Preferred Reporting Items for Systematic Review and Meta-analysis (PRISMA) guidance (32), as shown in the PRISMA checklist (Additional file 1). To provide full transparency and avoid study duplication, the systematic review was prospectively registered with PROSPERO (Prospective Register of Systematic Reviews); registration number: CRD42018083751.

\section{Study selection criteria}

Study design: Randomised trials, including cluster and randomised cross-over trials.

Studies where the interventions were compared to a control group (including no active treatment, wait list control, attention control, usual care) or alternative treatments were included. Studies were excluded where the main aim was to investigate the immediate 
medRxiv preprint doi: https://doi.org/10.1101/2021.05.27.21256673; this version posted May 29, 2021. The copyright holder for this preprint

effects of breaking up sitting time as part of a supervised (usually laboratory based) intervention.

Population: Studies involving adults only (as defined in the study), including both clinical and non-clinical populations.

Interventions: Any interventions for which a measure of sedentary behaviour was an outcome of interest including, for example, interventions which primarily aim to increase physical activity or promote weight loss but which also lead to changes in sedentary behaviour. Studies which evaluated interventions delivered primarily in schools, colleges, universities and workplaces were excluded.

Outcomes: To be included in the analysis, studies must include an outcome measuring time spent sedentary or the number of breaks in sedentary behaviour. The outcome could be measured using devices (e.g. accelerometer, inclinometer) or self-report questionnaires/scales (e.g. International Physical Activity Questionnaire (IPAQ) (33), Marshall Sitting Questionnaire (34)).

\section{Data sources and searches}

Data sources: In collaboration with information specialist colleagues, comprehensive search strategies were developed. Publication status, date and/or language restrictions were not applied. In October 2017, ten electronic databases (MEDLINE, Medline in Process \& Other Non-Indexed Citations, Embase, Cochrane Database of Systematic Reviews, CINAHL (Cumulative Index to Nursing and Allied Health Literature), PsycINFO, SportDiscus, Cochrane Central Register of Controlled Trials, Web of Science, ClinicalTrials.gov), The Sedentary Behaviour Research Network, the World Health Organisation and US Centres for Disease Control and Prevention websites, were searched. To identify further published, unpublished, and ongoing trials, we examined reference lists of previous reviews.

Search strategy: The search strategy for MEDLINE is shown as an exemplar in Additional file 2. This search strategy was adapted for use with the other electronic databases. Endnote 
medRxiv preprint doi: https://doi.org/10.1101/2021.05.27.21256673; this version posted May 29, 2021. The copyright holder for this preprint (which was not certified by peer review) is the author/funder, who has granted medRxiv a license to display the preprint in perpetuity.

It is made available under a CC-BY-NC-ND 4.0 International license .

x7 reference management software was used to manage and record data during the screening process.

Selection process: Two review authors (JFH, RC) independently screened all identified titles and abstracts and retained any that were potentially relevant. Full-text articles of these were obtained and assessed against the review's inclusion criteria independently by the same two authors. Papers that did not report any measures of time spent sedentary or time spent sitting were excluded. Disagreements were resolved through the involvement of a third reviewer (AF).

Data extraction and quality assessment: Two review authors (JFH, RC) piloted the data extraction form with an included study independently and discussed any discrepancies with extracted items. Following this, RC and JFH independently double-extracted $50 \%$ of the studies, then RC extracted the remaining studies. A full list of extracted items can be obtained from PROSPERO (CRD42018083751).

Two reviewers (NL, EG) independently assessed each trial's risk of bias in six domains (random sequence generation, allocation concealment, blinding of participants and personnel, blinding of outcome assessment, selective reporting, and incomplete outcome data) using the Cochrane Collaboration's tool for assessing risk of bias (35). For each domain, a judgement of high, low or unclear bias was made. Any discrepancies were resolved with involvement from a third reviewer $(\mathrm{RC})$.

The quality of evidence for each study was independently assessed by two reviewers (NL assessed $100 \%$ of the studies, RC double assessed $50 \%$ of the studies, JFH double assessed the remaining $50 \%$ of studies). Quality of evidence for the outcomes of 'total time spent sedentary' and 'number of breaks in sedentary behaviour' were assessed using the GRADEpro software (36), following the Grading of Recommendations Assessment, Development, and Evaluation (GRADE) system (37). Overall quality scores were determined using the following criteria: risk of bias, inconsistency, indirectness, imprecision, and publication bias. For each outcome, a judgement of high, moderate, low, or very low quality was applied. 
medRxiv preprint doi: https://doi.org/10.1101/2021.05.27.21256673; this version posted May 29, 2021. The copyright holder for this preprint (which was not certified by peer review) is the author/funder, who has granted medRxiv a license to display the preprint in perpetuity.

It is made available under a CC-BY-NC-ND 4.0 International license .

\section{Data synthesis and analysis}

Categorising interventions before conducting the meta-analysis: The interventions described in the included studies were diverse; therefore, categories were developed to group the interventions before undertaking the meta-analysis. The categories described the key components of the intervention, rather than categorising in terms of what the intervention intended to achieve e.g. a reduction in sedentary behaviour, or the methods used e.g. 'group-based'. To increase the rigour of categorisation, a group of four researchers (JFH, $R C, E G, A E)$ engaged in a three-stage process.

Stage One: Each researcher individually allocated all interventions to initial categories that were developed independently.

Stage Two: Consensus-based discussions between all the researchers were used to refine the categories.

Stage Three: The final categories were agreed by consensus between researchers and category descriptions were produced.

Stage Four: All interventions were allocated to one of the categories finalised in Stage Three through consensus-based discussions between the researchers.

Synthesis of results: Study characteristics, participant characteristics and intervention results were extracted and summarised in tabular form. Meta-analyses were conducted only where trials compared the differences between the intervention and control groups for the following outcomes: time spent sedentary (minutes per day) and breaks in sedentary behaviour (number of events per day). Where time spent sedentary was presented as hours per day, it was converted to minutes per day. Meta-analyses were performed using the generic inverse variance method and a random effects model in Review Manager Version

\section{3.}

Interventions were categorised using the consensus exercise described above, to compare their effectiveness for each outcome. For studies with multiple intervention groups within the same category, the intervention arms were pooled into one group to create a single pair-wise comparison, as recommended (38). In this review, we extracted data for measurements 
medRxiv preprint doi: https://doi.org/10.1101/2021.05.27.21256673; this version posted May 29, 2021. The copyright holder for this preprint (which was not certified by peer review) is the author/funder, who has granted medRxiv a license to display the preprint in perpetuity.

It is made available under a CC-BY-NC-ND 4.0 International license .

taken immediately post-intervention ("intervention end"), and the last follow-up where there was further follow-up beyond this time ("final follow-up"). Studies using devices to measure sedentary behaviour were analysed separately from studies using self-report measures.

Effect sizes were estimated using mean differences (MD) for devices, or standardised mean differences (SMD) for self-report data (35).

Heterogeneity was measured using the $\mathrm{I}^{2}$ statistic, with the aim to explore heterogeneity with subgroup analyses when any meta-analysis detected $\mathrm{I}^{2} \geq 50 \%$. When relevant data were not reported, study authors were contacted by email to request the required information. In cross-over trials, only data from the first phase of the trial was used in meta-analyses to guard against carry-over effects. Where cluster RCTs presented an estimate of the effect that accounts for the cluster design, this was used. Where no estimate of the effect was available, an intra-cluster correlation coefficient (ICC) was used (35). Where the ICC for an outcome was not available, an ICC of 0.01 was used (24).

\section{Results}

\section{Study selection}

The PRISMA flow diagram is shown in Figure 1. The search strategy identified 39,223 articles through database searches, and 1,010 articles were added after screening reference lists. After duplicates were removed $(n=11,755), 28,478$ titles and abstracts were screened, and 27,896 articles were excluded as they did not meet the pre-defined eligibility criteria. Following this, 582 full texts of articles were assessed, of which 499 articles were excluded (Figure 1). In total, 83 full-text articles were included, which comprised 85 studies (two articles contained data from two RCTs each $(39,40))$. All studies were reported in English. Sufficient data were available for 55/85 studies to be included in the meta-analyses. 


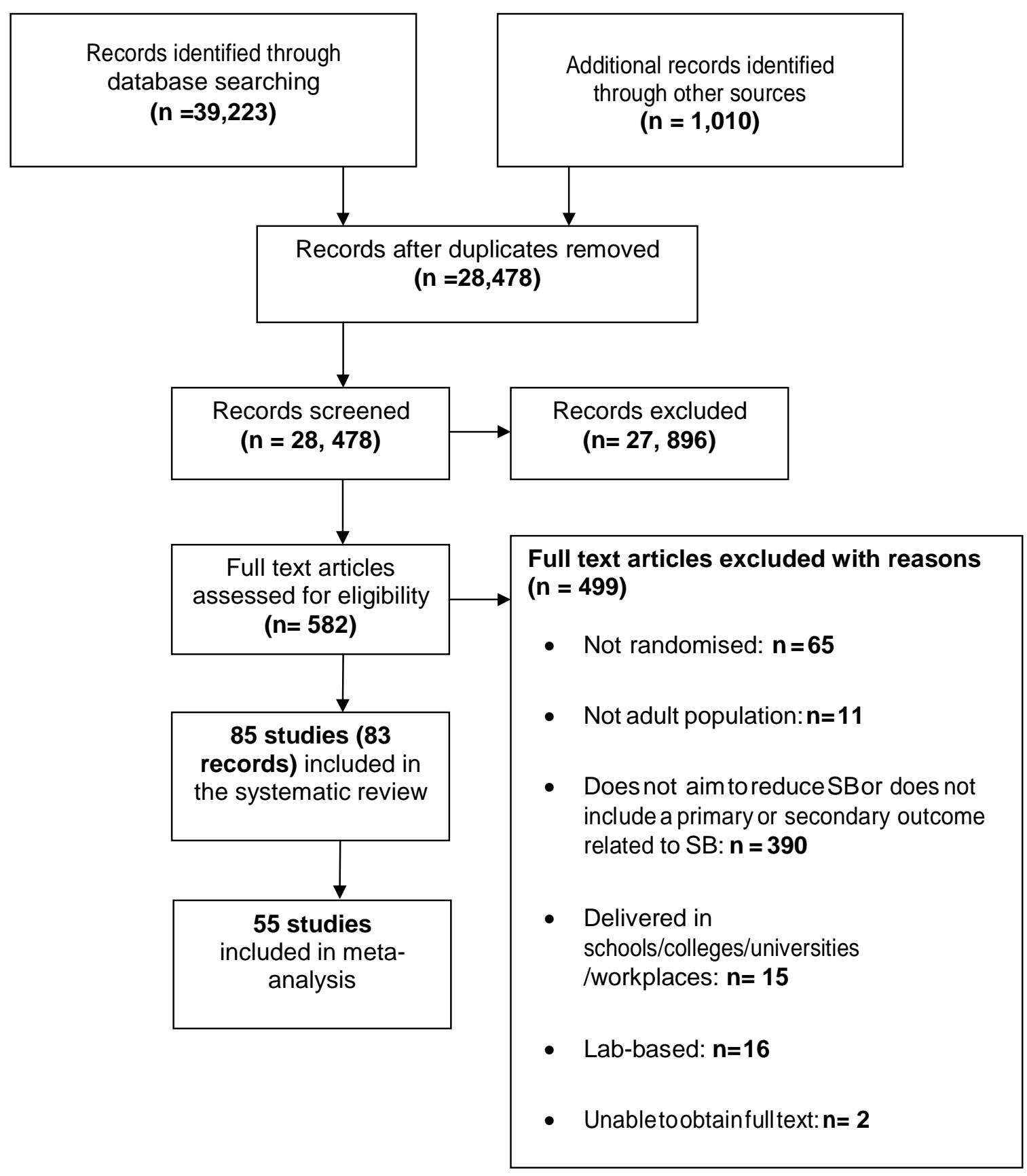

Figure 1: PRISMA flow diagram

\section{Study characteristics}

The Table of characteristics for included studies is shown in Additional file 3; 85 studies from

83 articles were included. Eighty of the 85 included studies evaluated interventions using

RCTs (39-116), and five studies used cluster RCTs; clusters included weight loss groups 
medRxiv preprint doi: https://doi.org/10.1101/2021.05.27.21256673; this version posted May 29, 2021. The copyright holder for this preprint

(117), local government areas (118), senior centres (119), GP practices (120), or intellectual disabilities community-based organisations (121) as the unit of randomisation. Thirty-nine studies were conducted in Europe $(41,43,44,47,48,51,52,54-58,65-67,69,73,75,78$, $79,81,82,89,94-97,99,100,103,105,110-112,114,116,120-122) ; 32$ were from North America $(39,40,42,45,50,53,59,60,62,63,68,71,74,76,77,80,83-85,92,93,98$, 101, 106-109, 115, 117, 119); ten were from Australia (46, 49, 61, 64, 72, 87, 91, 104, 113, 118); and four were from Asia $(70,86,88,102)$. Seven studies used a no intervention control group $(48,49,64,65,81,85,108)$; control participants were asked to maintain their usual lifestyle or were provided usual care in 24 studies $(41,43,44,46,54-58,66,69,70,75,90$, $91,93,96,99,101,102,110,111,113,118)$; eleven studies used a wait-list control arm (39, $50,62,72,80,83,87,89,117,121) ; 16$ studies used an attention control arm $(42,51,53$, $61,63,68,73,77,79,84,86,92,95,98,109,119)$; eleven studies used a minimal intervention $(47,60,76,78,88,97,103-105,112,115)$ and 16 studies compared more than one intervention with each other without the use of a control $(40,45,52,55,59,74,82,88$, $90,94,100,106,107,116,120)$.

Fourteen studies focused on reducing sedentary behaviour $(41,47,53,60-62,81,92,107$, 110-112, 117, 119); 34 focused on increasing physical activity $(43,48,51,54,55,59,64-66$, $68,71,73-76,79,80,83,84,88-91,95,97,98,102-105,108,114-116) ; 12$ focused on both reducing sedentary behaviour and increasing physical activity $(42,44-46,56,57,67,77,86$, $94,113,121)$ and 25 focused on other behaviours such as diet, smoking, or alcohol intake in addition to sedentary behaviour and/or physical activity or both $(39,40,49,50,52,58,63$, $69,70,72,78,82,85,87,93,96,99-101,106,109,118,120)$. Sedentary behaviour was measured using devices only (34/85 studies), self-report measures only (39/85 studies), or a combination of both devices and self-report measures (12/85 studies). Regarding the devices, $43 / 46$ studies used accelerometers, and 3/46 used devices attached to the TV to monitor screen time. The most commonly used devices were ActiGraphs ${ }^{\mathrm{TM}}$ and ActivPALs ${ }^{\mathrm{TM}}$. Self-report measures were more diverse, with the use of various activity logs and 
medRxiv preprint doi: https://doi.org/10.1101/2021.05.27.21256673; this version posted May 29, 2021. The copyright holder for this preprint (which was not certified by peer review) is the author/funder, who has granted medRxiv a license to display the preprint in perpetuity.

It is made available under a CC-BY-NC-ND 4.0 International license .

questionnaires, e.g. International Physical Activity Questionnaire (IPAQ) (33), Yale Physical Activity Survey (YPAS) (123), past-week Modifiable Activity Questionnaire (PWMAQ) (124), Harokopio Physical Activity Questionnaire (125), Marshall Sitting Questionnaire (34), and Sedentary and Light Intensity Physical Activity Log (126).

In total, 33,074 participants took part in the 85 included studies. The median sample size was 102 , with a range from 20 (110) to 12,287 participants (65). On average, $66 \%$ of participants were female. The proportion of females in the studies of mixed sexes ranged between $13 \%$ and $92 \%$; five studies included only male participants $(39,73,87,95,114)$, and 20 studies included only female participants $(39,42,58,63,68,70,71,74,79,82,93$, $96,98,99,103,104,109,115,117,118)$. The median of the mean age of study participants was 52 years, ranging from 18 years $(73,95)$ to 82 years $(91)$.

Twenty-four studies targeted overweight participants (39, 40, 44, 47, 50, 57, 58, 63, 69, 75, 76, 82, 83, 87, 92-94, 96, 101, 107, 117, 120); eleven studies targeted participants with Type 2 diabetes $(44,52,56,57,86,102)$, gestational diabetes (70), or those at risk of Type 2 or gestational diabetes $(47,68,78,101)$. Other clinical conditions used as inclusion criteria in studies included rheumatoid arthritis $(110,111)$, chronic obstructive pulmonary disease $(48$, 54, 113), multiple sclerosis (84), dementia (119), depression (67), a history of myocardial infarction (90), cancer $(72,98,104)$, and stroke (61).

\section{Intervention categorisation}

Fourteen categories of interventions were identified by the categorisation process, including three single-component, and eleven multi-component interventions (see Table 1). 


\section{Table 1: Definition of intervention categories}

\begin{tabular}{|c|c|c|}
\hline & Intervention categories & Description \\
\hline \multirow{5}{*}{$\begin{array}{l}\text { Single } \\
\text { component } \\
\text { interventions }\end{array}$} & $\begin{array}{l}\text { Activity Monitoring (AM) } \\
\text { (Four interventions) }\end{array}$ & $\begin{array}{l}\text { Interventions that included a device to measure activity (including pedometers, activity monitors such as Fitbits } \\
\text { or smartphone applications) as a key/central component and incorporated feedback, goal setting and self- } \\
\text { monitoring due to the nature of some of the devices. }\end{array}$ \\
\hline & $\begin{array}{l}\text { Counselling (Co) } \\
\text { (Five interventions) }\end{array}$ & $\begin{array}{l}\text { Interventions that included counselling as part of the intervention description or a recognised type of } \\
\text { counselling, e.g. motivational interviewing, cognitive behaviour therapy. } \\
\text { - Not just advice; support; or giving solutions and ideas; but these components could be included as part of } \\
\text { counselling type interventions. } \\
\text { - This did not necessarily have to be delivered by a trained counsellor, but they would be practising } \\
\text { recognised techniques. }\end{array}$ \\
\hline & $\begin{array}{l}\text { Structured/prescribed physical } \\
\text { activity (PA) } \\
\text { (Eight interventions) }\end{array}$ & $\begin{array}{l}\text { Interventions that included structured or prescribed exercise regimes including walking, yoga, dance, gym- } \\
\text { based training programmes. These could be either group based or individual and included exercise contracts. }\end{array}$ \\
\hline & $\begin{array}{l}\text { Information/Education/Support } \\
(\text { IES)* } \\
\text { (Fourteen interventions) }\end{array}$ & $\begin{array}{l}\text { Interventions that included information/education/support in the description or had the following features: } \\
\text { The intervention informed/instructed, educated or supported participants by providing advice, solutions, or } \\
\text { recommendations. This could be in the form of something tangible e.g. a booklet, newsletter, text messages, } \\
\text { an online app, or verbally in a one-to-one or group settings. }\end{array}$ \\
\hline & $\begin{array}{l}\text { IES + AM } \\
\text { (Eleven interventions) }\end{array}$ & Interventions that included the provision of information, education or support and the use of an activity monitor. \\
\hline
\end{tabular}




\begin{tabular}{|c|c|c|}
\hline \multirow{9}{*}{$\begin{array}{l}\text { Multi- } \\
\text { component } \\
\text { interventions }\end{array}$} & $\begin{array}{l}\text { IES + AM + PA } \\
\text { (Eight interventions) }\end{array}$ & $\begin{array}{l}\text { Interventions that included the provision of information, education or support, the use of an activity monitor, and } \\
\text { a physical activity component. }\end{array}$ \\
\hline & $\begin{array}{l}\text { IES + Co } \\
\text { (Ten interventions) }\end{array}$ & Interventions that included the provision of information, education or support and a counselling component. \\
\hline & $\begin{array}{l}\text { IES + Co + AM } \\
\text { (Five interventions) }\end{array}$ & $\begin{array}{l}\text { Interventions that included the provision of information, education or support, counselling, and the use of an } \\
\text { activity monitor. }\end{array}$ \\
\hline & $\begin{array}{l}\text { IES + Co + PA } \\
\text { (Two interventions) }\end{array}$ & $\begin{array}{l}\text { Interventions that included the provision of information, education or support, counselling, and a physical } \\
\text { activity component. }\end{array}$ \\
\hline & $\begin{array}{l}\text { IES + Pharmacological } \\
\text { (One intervention) }\end{array}$ & $\begin{array}{l}\text { Interventions that included the provision of information, education or support, and a pharmacological } \\
\text { component (e.g. Metformin, a medicine to treat Type } 2 \text { diabetes). }\end{array}$ \\
\hline & $\begin{array}{l}\text { IES + PA } \\
\text { (Seven interventions) }\end{array}$ & Interventions that included the provision of information, education or support and a physical activity component. \\
\hline & $\begin{array}{l}\mathrm{AM}+\mathrm{Co} \\
\text { (One intervention) }\end{array}$ & Interventions that included the provision of an activity monitor, and a counselling component. \\
\hline & $\begin{array}{l}\text { Co + PA } \\
\text { (Three interventions) }\end{array}$ & Interventions that included a combination of counselling and physical activity components. \\
\hline & $\begin{array}{l}\mathrm{IES}+\mathrm{Co}+\mathrm{AM}+\mathrm{PA} \\
\text { (One intervention) }\end{array}$ & $\begin{array}{l}\text { Interventions that included the provision of information, education or support, the use of an activity monitor, } \\
\text { counselling and a physical activity component. }\end{array}$ \\
\hline
\end{tabular}

${ }^{\star}$ Researchers found it was not always possible to confidently disentangle the provision of information, education, or support in the interventions. These items were often interlinked and so, following a consensus-based decision, these items were placed together as a multi-component category. Therefore, although a 
combination of two or three of these elements were often present in studies within this category, this was not always the case. All other interventions

categorised as multi-component in the table are either a combination of IES and single components, or combinations of the other single components within the table. 
medRxiv preprint doi: https://doi.org/10.1101/2021.05.27.21256673; this version posted May 29, 2021. The copyright holder for this preprint (which was not certified by peer review) is the author/funder, who has granted medRxiv a license to display the preprint in perpetuity.

It is made available under a CC-BY-NC-ND 4.0 International license .

\section{Risk of bias}

Figure 2 shows a summary of the risk of bias assessment. The following domains were graded as having the largest proportion of high risk of bias: performance bias (the absence of blinding of participants and personnel), detection bias (a lack of blinding of the outcome assessment), and attrition bias (incomplete outcome data reported). Unclear risk of bias judgements were commonly applied to both aspects of selection bias (random sequence generation and allocation concealment) and reporting bias (selective reporting). We examined funnel plots for all comparisons of intervention vs. control, from which there was no evidence of publication bias. We did not examine funnel plots for individual intervention categories as there were too few studies in each group.

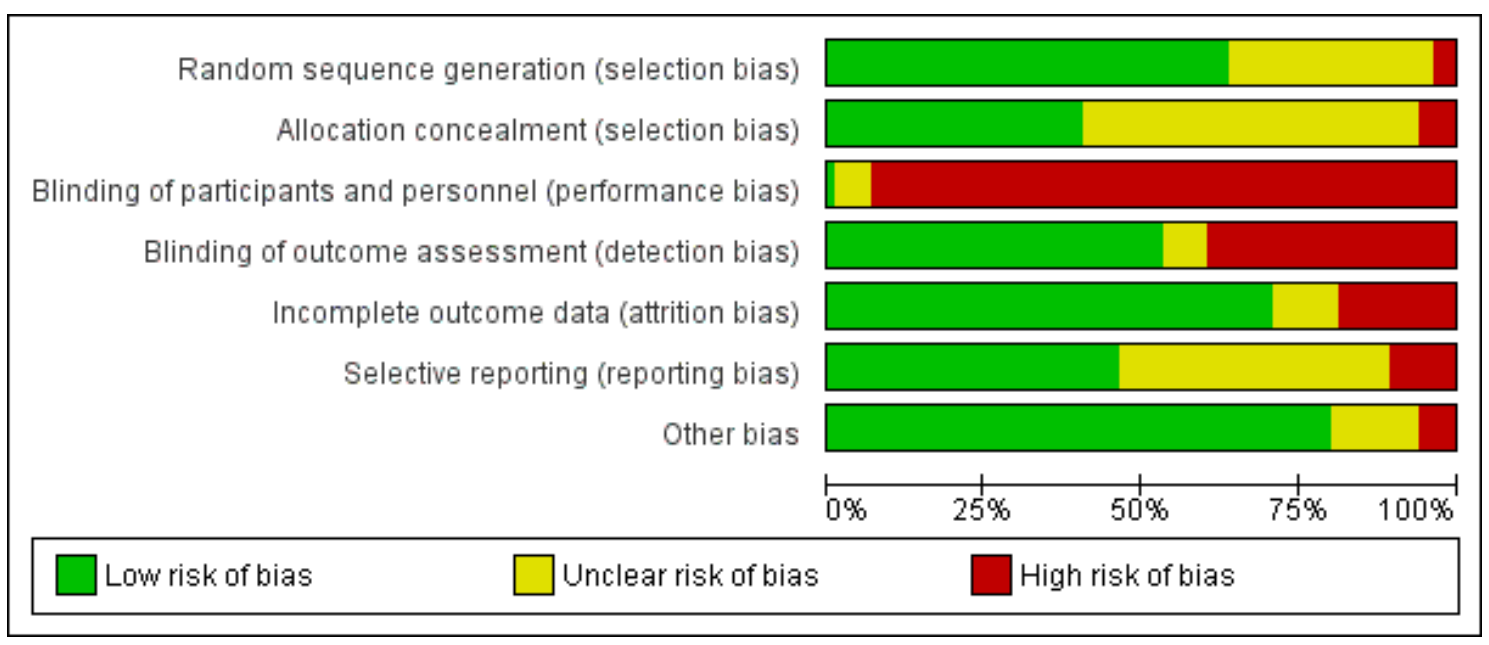

Figure 2: Summary of the risk of bias assessment for included studies

\section{Effects of intervention categories}

Studies were pooled in meta-analyses and stratified according to the outcome (time spent sedentary, or number of breaks in sedentary behaviour), how the outcome was measured (using a device, or self-report), and timing of follow-up (intervention end, or final follow-up). Analyses were conducted to explore the relative effectiveness of different intervention categories. 
medRxiv preprint doi: https://doi.org/10.1101/2021.05.27.21256673; this version posted May 29, 2021. The copyright holder for this preprint (which was not certified by peer review) is the author/funder, who has granted medRxiv a license to display the preprint in perpetuity.

It is made available under a CC-BY-NC-ND 4.0 International license .

\section{Time spent sedentary}

In total, 44 studies assessed time spent sedentary using devices. Twenty-nine studies reported sufficient data to be included in the meta-analyses. Of the fourteen intervention categories, seven had results from multiple studies which were pooled, five had results from a single study and two had no relevant outcome data (see Figure 3). Only one of the pooled analyses was statistically significant; interventions that incorporated the provision of information, education, or formal support (IES), in addition to a form of counselling (Co) reduced time spent sedentary on average by $\mathrm{MD}$ of -52.24 minutes per day $(95 \% \mathrm{Cl}-85.37$ to $\left.-19.10, p=0.002 ; l^{2}=0 \% ; n=170\right)$; the GRADE certainty of confidence is moderate. Two other intervention categories with results from single studies showed significant reductions in time spent sedentary: IES + Co + structured/prescribed physical activity (PA) (MD of -60 minutes per day, $95 \% \mathrm{Cl}-94.81$ to $-25.19, p=0.0007 ; n=126)$; the GRADE certainty of confidence is low, and Co + PA (MD of -42 minutes per day, $95 \% \mathrm{Cl}-59.65$ to -24.35 , $p<0.00001 ; n=300)$; the GRADE certainty of confidence is moderate.

Only 9 studies reported further follow-up beyond the end of intervention, with follow-up periods ranging from 12 to 40 weeks post-intervention. The pooled analyses showed no indication of sustained effectiveness after the end of interventions; however the single study of IES + Co + PA did show a significant reduction in time spent sedentary at 6 months postintervention (MD of -96 minutes per day, $95 \% \mathrm{Cl}-131.22$ to $-60.78, p<0.00001 ; n=97$ ); the GRADE certainty of confidence is very low (see Figure 4). 
medRxiv preprint doi: https://doi.org/10.1101/2021.05.27.21256673; this version posted May 29, 2021. The copyright holder for this preprint (which was not certified by peer review) is the author/funder, who has granted medRxiv a license to display the preprint in perpetuity.

It is made available under a CC-BY-NC-ND 4.0 International license .

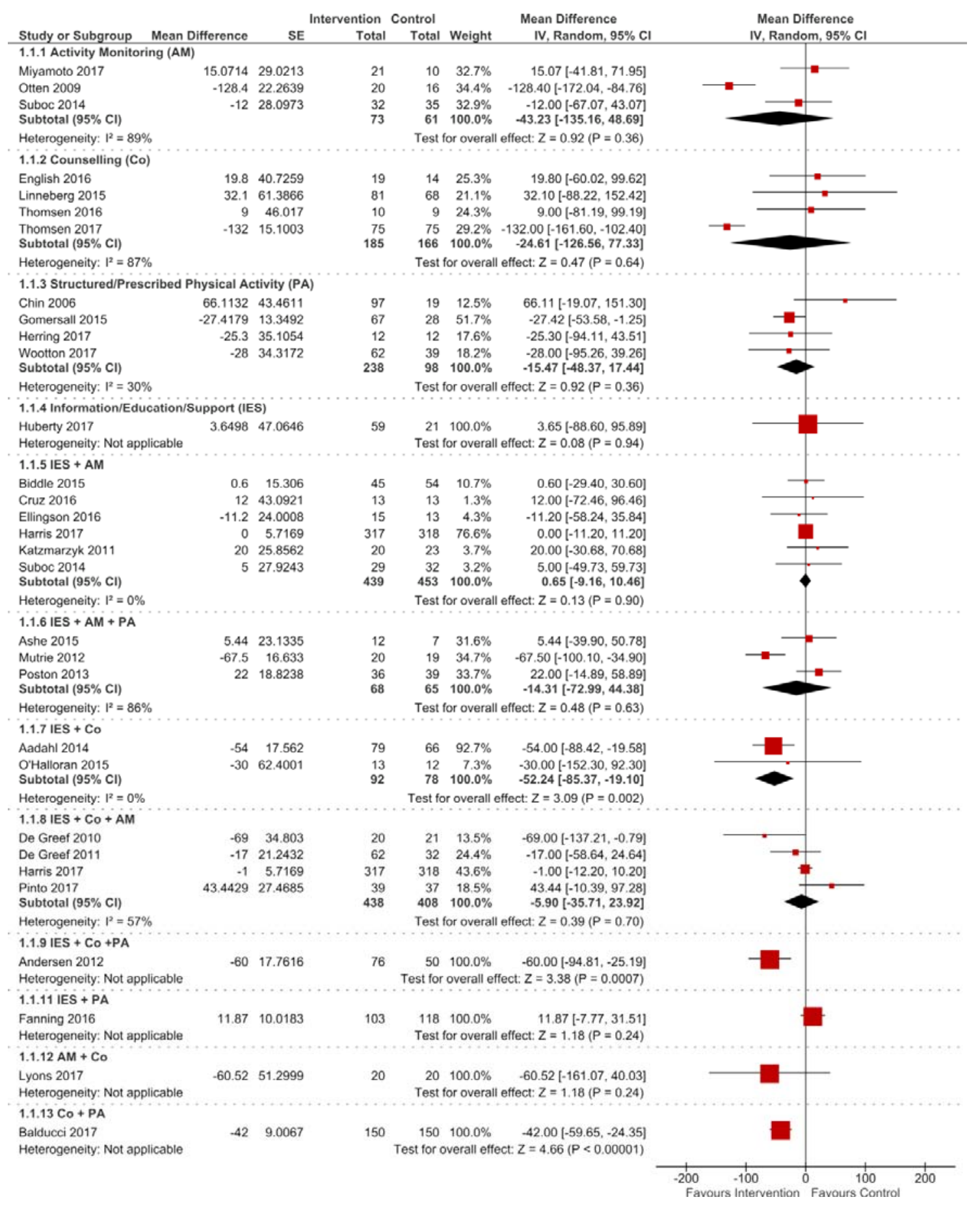

Figure 3: Forest plots showing effects of intervention categories to reduce time spent sedentary measured using devices (at intervention end) *

*Results for intervention categories with a minimum of two studies (7/14) were pooled. Two intervention categories (2/14) had no relevant outcome data (IES + Pharmacological; IES + Co + AM

$+\mathrm{PA})$. 
medRxiv preprint doi: https://doi.org/10.1101/2021.05.27.21256673; this version posted May 29, 2021. The copyright holder for this preprint (which was not certified by peer review) is the author/funder, who has granted medRxiv a license to display the preprint in perpetuity.

It is made available under a CC-BY-NC-ND 4.0 International license .

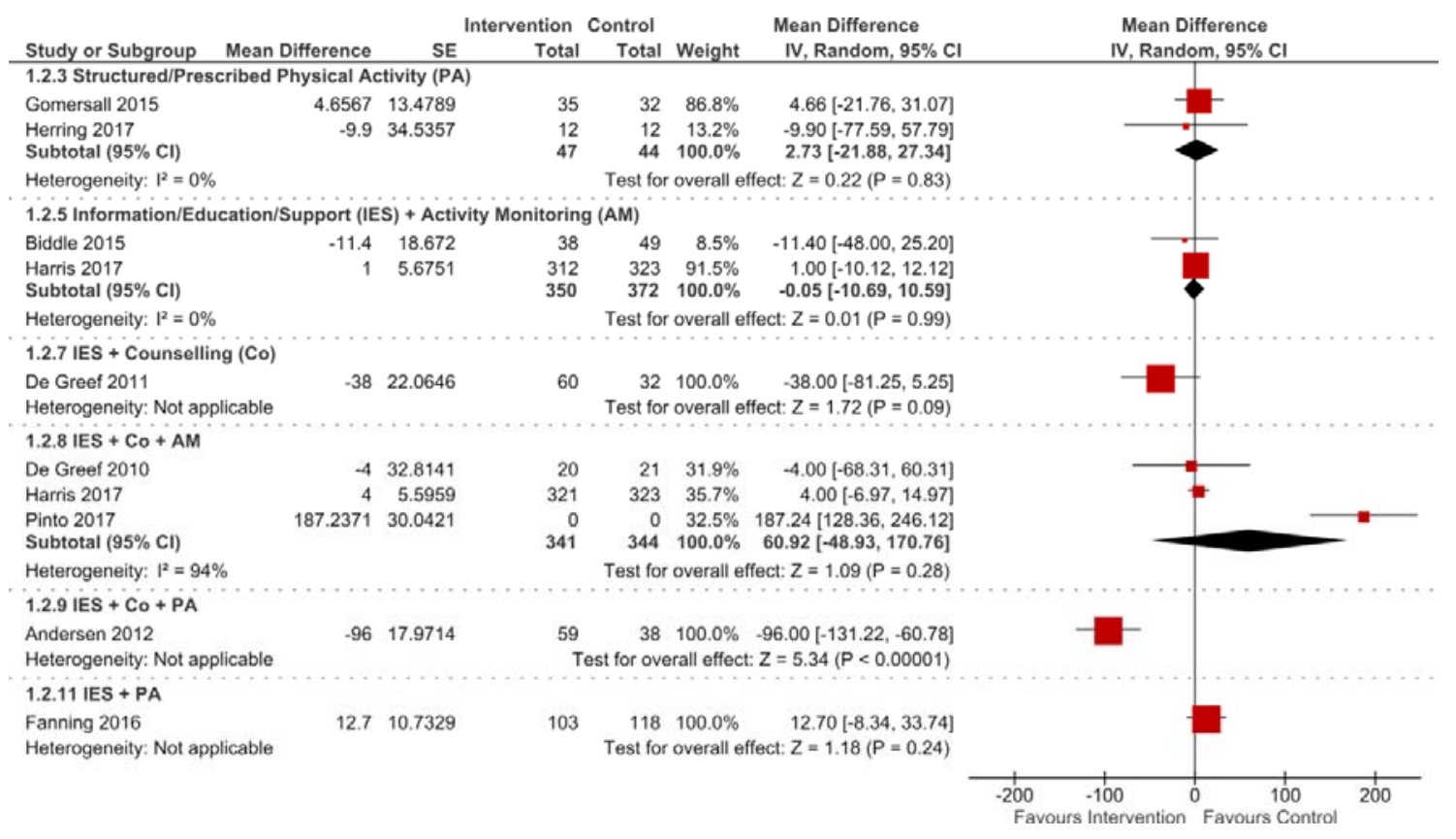

Figure 4: Forest plots showing effects of intervention categories to reduce time spent sedentary measured using devices (final follow-up) ${ }^{\star}$

${ }^{*}$ Results for intervention categories with a minimum of two studies (3/14) were pooled. Eight intervention categories (8/14) had no relevant outcome data: AM; Co; IES; IES + AM + PA; IES + Pharmacological; AM + Co; Co + PA; IES + Co + AM + PA.

In total, 40 studies assessed time spent sedentary using self-report measures. Twenty-six studies reported sufficient data to be included in the meta-analyses. Of the fourteen intervention categories, five had results from multiple studies which were pooled, four had results from a single study and five had no relevant outcome data (see Figure 5). Only one of the pooled analyses was statistically significant; interventions that incorporated the provision of information, education, or formal support, in addition to a structured/prescribed physical activity component reduced time spent sedentary on average by a significant, albeit small, effect size of SMD of $-0.15\left(95 \% \mathrm{Cl}-0.23\right.$ to $-0.07 ; Z=3.76, p=0.0002 ; I^{2}=0 \% ; n=$ 2419); the GRADE certainty of confidence is moderate. 
medRxiv preprint doi: https://doi.org/10.1101/2021.05.27.21256673; this version posted May 29, 2021. The copyright holder for this preprint (which was not certified by peer review) is the author/funder, who has granted medRxiv a license to display the preprint in perpetuity.

It is made available under a CC-BY-NC-ND 4.0 International license.

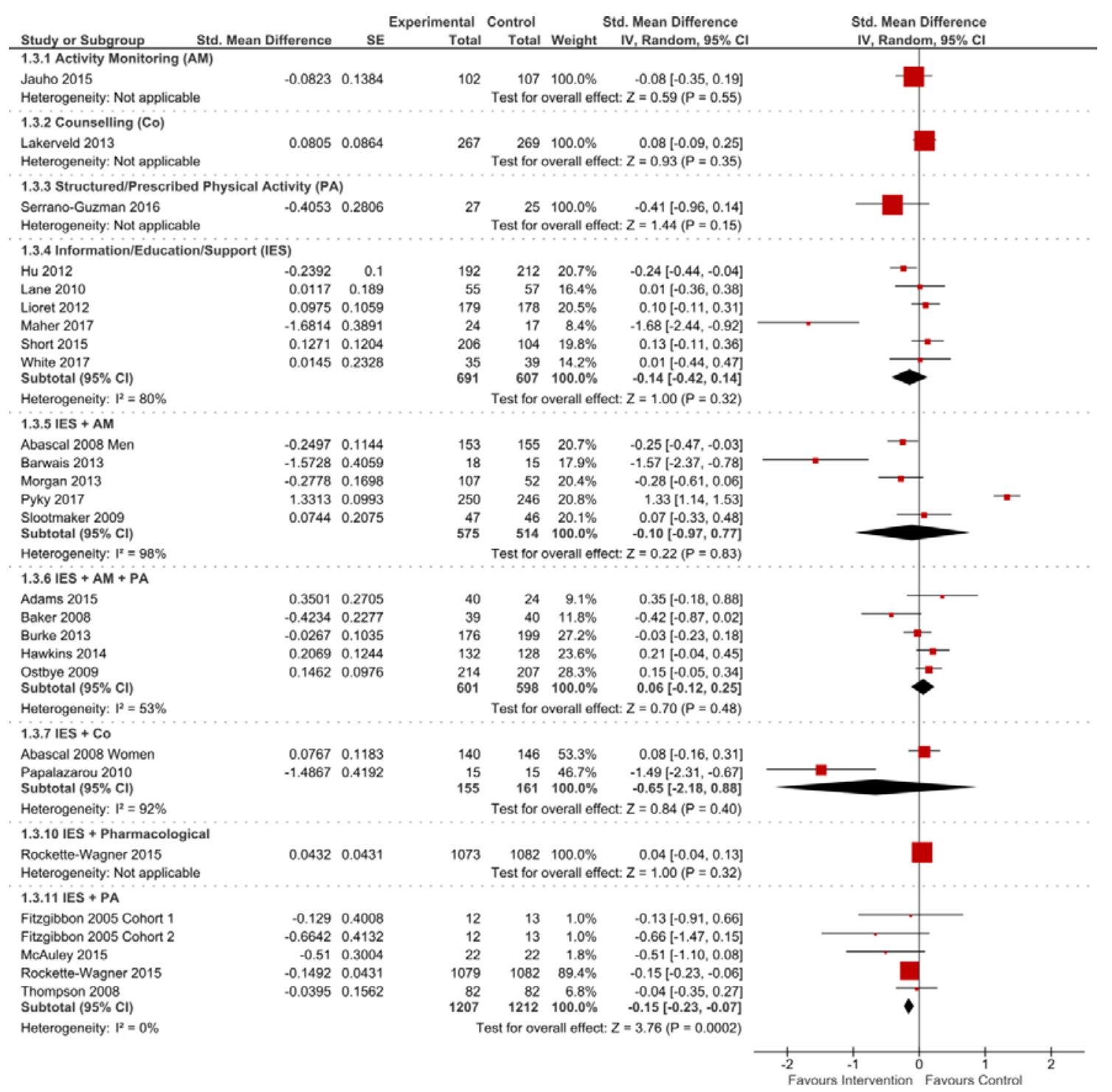

Figure 5: Forest plots showing effects of intervention categories to reduce time spent sedentary using self-report outcome measures (at intervention end) *

${ }^{*}$ Results for intervention categories with a minimum of two studies (5/14) were pooled. Five intervention categories had no relevant outcome data: IES + Co + AM; IES + Co + PA; AM + Co; Co + $P A ; I E S+C o+A M+P A$.

Only 5 studies reported further follow-up beyond the end of intervention, with follow-up periods ranging from 4 weeks to 18 months post-intervention. The pooled analysis showed no indication of sustained effectiveness after the end of intervention (see Figure 6); however the single study of an intervention that incorporated the provision of information, education or 
medRxiv preprint doi: https://doi.org/10.1101/2021.05.27.21256673; this version posted May 29, 2021. The copyright holder for this preprint (which was not certified by peer review) is the author/funder, who has granted medRxiv a license to display the preprint in perpetuity.

It is made available under a CC-BY-NC-ND 4.0 International license .

formal support, in addition to activity monitoring did show a statistically significant reduction in time spent sedentary at 3 months post-intervention (SMD of $-0.54,95 \% \mathrm{Cl}-0.88$ to -0.21 , $p=0.002 ; n=159) ;$ the GRADE certainty of confidence is low.

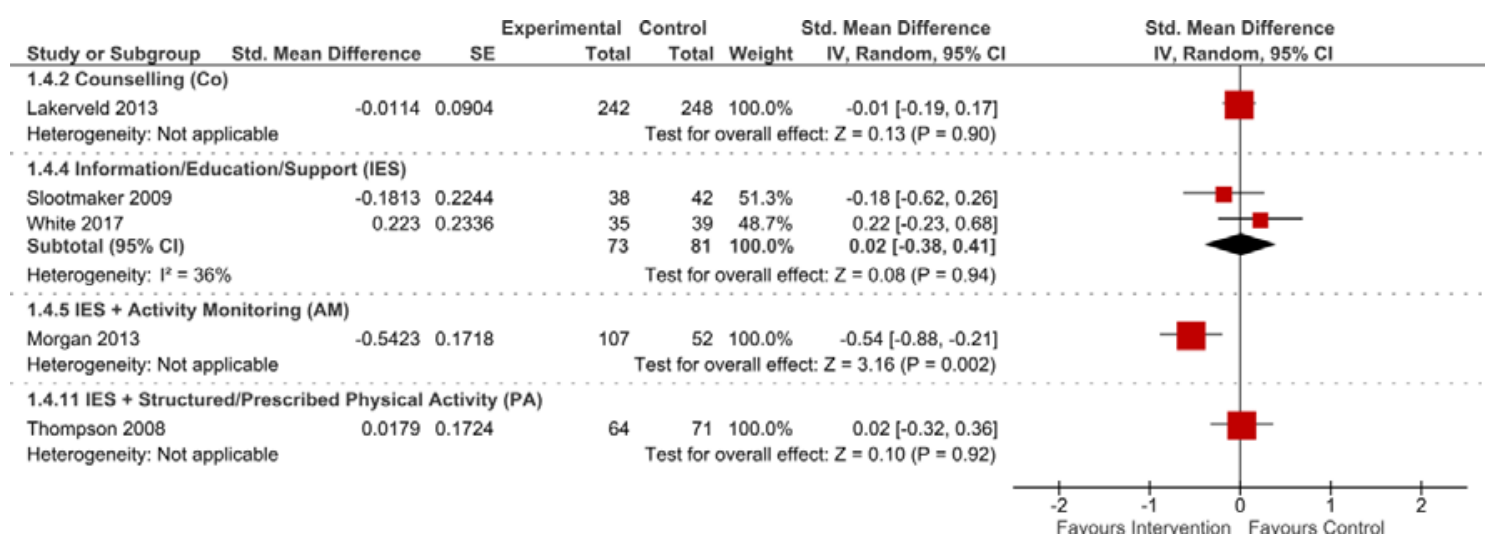

Figure 6: Forest plots showing effects of intervention categories to reduce time spent sedentary using self-report outcome measures (final follow-up)*

*Results for intervention categories with a minimum of two studies (1/14) were pooled. Ten intervention categories had no relevant outcome data: Activity Monitoring (AM); Structure/Prescribed Physical Activity (PA); IES + AM + PA; IES + Co; IES + Co + AM; IES + Co + PA; IES + Pharmacological; AM + Co; Co + PA; IES + Co + AM + PA.

\section{Number of breaks in sitting time}

In total, four studies assessed the number of breaks in prolonged sitting using devices (see Figure 7). Of the fourteen intervention categories, only one (counselling) had results from multiple studies which were pooled, two had results from a single study and the remaining eleven had no relevant outcome data (see Figure 7). Counselling interventions did not show an effect in favour of the interventions $\left(S M D=2.18 ; 95 \% \mathrm{Cl}-1.44\right.$ to $5.80, p=0.24 ; I^{2}=0 \%$; $n=169)$; the GRADE certainty of confidence is moderate.

Only one study reported further follow-up beyond the end of intervention and this did not show a significant effect (intervention incorporating information, education or formal support 
medRxiv preprint doi: https://doi.org/10.1101/2021.05.27.21256673; this version posted May 29, 2021. The copyright holder for this preprint (which was not certified by peer review) is the author/funder, who has granted medRxiv a license to display the preprint in perpetuity.

It is made available under a CC-BY-NC-ND 4.0 International license .

in addition to structured/prescribed physical activity: $\mathrm{SMD}=2.57 ; 95 \% \mathrm{Cl}-1.85$ to $6.99, \mathrm{p}=$ $0.25 ; n=221$ ); the GRADE certainty of confidence is moderate.

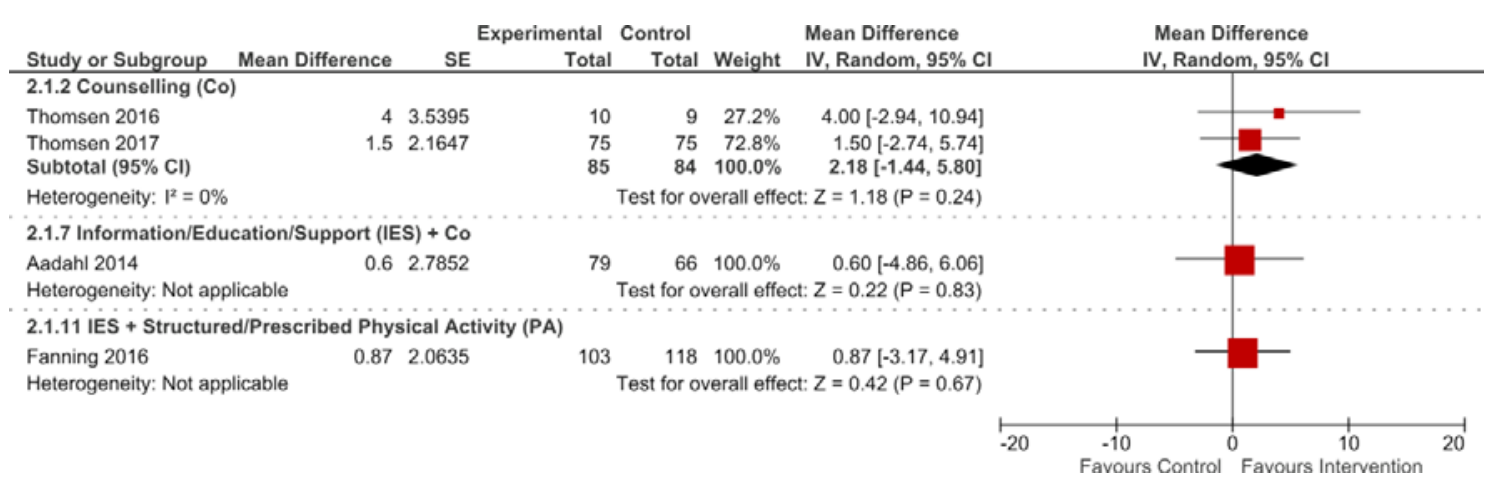

Figure 7: Forest plots showing effects of interventions to increase the number of breaks in sitting time using devices (at intervention end) *

${ }^{*}$ Results of intervention categories with a minimum of two studies (1/14) were pooled. Eleven intervention categories had no relevant outcome data: Activity Monitoring (AM); Structured/Prescribed Physical Activity (PA); Information/Education/Support (IES); IES + AM; IES + AM + PA; IES + Co + $A M ; I E S+C o$ + PA; IES + Pharmacological; AM + Co; Co + PA; IES + Co + AM + PA.

\section{Discussion}

This systematic review and meta-analysis explored the effects of interventions to reduce time spent sedentary and increase the number of breaks in sedentary behaviour by breaking up prolonged bouts of sitting. The majority of the results in meta-analyses were not statistically significant in favour of the interventions and most evidence was not of a high quality. Meta-analyses suggest that only interventions which focused on providing participants information, education, or formal support (such as advice or recommendations), in conjunction with either counselling (such as motivational interviewing) or with structured/prescribed physical activity (such as a walking group) led to reductions in total time spent sedentary immediately post-intervention, when measured with devices only or self-report only, respectively. Interestingly, results from a single RCT showed that an intervention which provided information, education or formal support in conjunction with counselling and with structured/prescribed physical activity also led to reductions in 
medRxiv preprint doi: https://doi.org/10.1101/2021.05.27.21256673; this version posted May 29, 2021. The copyright holder for this preprint

objectively measured total time spent sedentary immediately post-intervention and this was sustained at 6 months follow-up (114). There were very few studies, with very few participants, assessing the effect of interventions on increasing the number of breaks in sedentary behaviour; only one meta-analysis could be performed, which did not show any effectiveness of counselling interventions to increase the number of breaks in sedentary behaviour.

Evidence from preceding reviews and meta-analyses indicate the potential for interventions to reduce sedentary behaviour across a range of populations (23-27). Research suggests that reallocating 30 minutes per day of sedentary behaviour to light physical activity is clinically beneficial, with the impact even stronger when reallocating the same amount of sedentary behaviour to MVPA (127-130).

The present review is consistent with previous reviews, demonstrating that it is possible to reduce sedentary behaviour by over 30 minutes per day. In our pooled analyses we found only one intervention category reduced sedentary behaviour immediately post-intervention by more than 30 minutes per day (interventions incorporating information, education, or formal support, with counselling reduced sedentary behaviour by 52 minutes per day; measured objectively by devices). A single study reported an even larger effect for an intervention incorporating information, education, or formal support in conjunction with counselling and structured/prescribed physical activity (showing a reduction in sedentary behaviour by 60 and 92 minutes per day immediately and 6 months post-intervention, respectively) (114). We also found interventions incorporating information, education, or formal support, with a structured/prescribed physical activity component showed on average a small but statistically significant reduction in sedentary behaviour (measured by self-report measures). This finding is supported by recent work reviewing sedentary behaviour interventions in overweight and obese participants. Zabatiero et al. (131) found that 
medRxiv preprint doi: https://doi.org/10.1101/2021.05.27.21256673; this version posted May 29, 2021. The copyright holder for this preprint

education alone was not sufficient to reduce sedentary behaviour, and that the inclusion of a physical activity component was important for the success of interventions.

To our knowledge, this is the first review to utilise a rigorous process to precisely categorise interventions, in order to unpick the combination of components that could be effective for reducing sedentary behaviour. Previous meta-analyses have combined interventions according to similar outcome measures $(23,24,28)$; or they have used broad categories. Peachey et al. (30) broadly categorised interventions as behavioural, environmental, or multi-component in their review; in the subgroup analyses by Shrestha et al. (28), broad categories of interventions such as educational, multi-component, TV restricting, and workplace were used. The recently published review by Blackburn et al. (29) applied similar broad categories and also examined the level of complexity of interventions, based on a number of different dimensions including number of components, targeted behaviours and level of skill required. They found that environmental interventions targeting reductions in sedentary behaviour were particularly successful. They concluded that interventions may need to be more complex to address the multi-faceted nature of sedentary behaviour, although reported that a higher level of complexity was not necessarily associated with better outcomes in terms of sustained change.

Due to the nature of the categorising of interventions, the present review had fewer studies in each meta-analysis than previous reviews with broader categories. However, the aims of the present review were to better understand the key components within the interventions, and to examine whether there were particular categories of interventions that showed effectiveness. Although two intervention categories showed benefits, the small number of studies and the quality of data limit the interpretation of findings. The categories of interventions developed during the conduct of this review provide a novel method of interpreting the sedentary behaviour literature. We hope to provide a springboard for future 
medRxiv preprint doi: https://doi.org/10.1101/2021.05.27.21256673; this version posted May 29, 2021. The copyright holder for this preprint

evidence syntheses to develop, refine and build consensus for classifying interventions which is different from categorising interventions according to behaviour change techniques.

The findings of the present review are informative for researchers, clinicians and public health professionals, but it is important to be mindful of the context of interest when translating these results into practice. When applying the evidence about the categories of interventions that showed potential, more work is required to establish the finer details of the interventions, e.g. context, mechanisms of action, and delivery for a given population. Future interventions must account for contextual factors such as the physical environment (132, 133), the social and cultural environment (134), the age of participants (18), and the types of sedentary behaviours performed and which of these sedentary behaviours would be most acceptable to change for individuals (135). Thus, future research in this area should consider the reporting of qualitative intervention development work, an improved reporting of interventions, e.g. using the Template for Intervention Description and Replication (TIDieR) checklist (136), use of outcome measures that capture the amount and types of sedentary behaviour $(137,138)$, and conducting process evaluations to help to disentangle why and in which contexts interventions are effective or ineffective (139).

\section{Strengths and limitations}

Robust methods were used throughout the conduct of the review. A comprehensive search strategy was developed with input from an information specialist; two review authors independently screened search results and assessed the quality of included studies using the GRADE approach. When data were available, the estimates of the intervention effects were synthesised using meta-analyses and adjusted for clustering where necessary. However, caution should be used when interpreting the findings due to the limitations of the review, which largely relate to the nature of the evidence base. Although efforts were made to combine studies with similar outcomes, there was variation in the tools used to measure 
medRxiv preprint doi: https://doi.org/10.1101/2021.05.27.21256673; this version posted May 29, 2021. The copyright holder for this preprint

outcomes across studies, and considerable variation in the self-report outcome measures used to measure sedentary behaviour. We acknowledge that in future work, it is necessary to separately assess outcome measures, such as TV viewing time, screen time, time spent sitting, and time spent sedentary, to allow for a more accurate interpretation of findings (138). This may in part account for the heterogeneity in the present review. However, it could also be due to other forms of heterogeneity such as differences in population and intervention. The meta-analyses were limited by having a small number of studies with a small number of participants for each outcome, which precluded an examination of heterogeneity by subgroup analyses. Finally, the risk of bias assessment within studies and the GRADE assessment across outcomes showed that most of the quality of evidence was low to moderate, primarily due to relatively small sample sizes and/or wide confidence intervals indicative of imprecision of results. In addition, high risk of performance and detection bias was commonly found in the studies, because blinding was difficult in the majority of these behavioural change interventions.

\section{Conclusions}

To our knowledge, this is the first systematic review of effects of interventions on sedentary behaviour to precisely categorise interventions according to the types of components they comprised. From the limited pool of studies, findings suggest that the most promising interventions were those that were composed of the provision of information, education, or formal support with behaviour change counselling, or the provision of information, education, or formal support and structured/prescribed physical activity. There were limited studies measuring sustained behaviour change. Future interventions would benefit from focusing on the long-term maintenance of reduced sedentary behaviour.

\section{Acknowledgements}


medRxiv preprint doi: https://doi.org/10.1101/2021.05.27.21256673; this version posted May 29, 2021. The copyright holder for this preprint (which was not certified by peer review) is the author/funder, who has granted medRxiv a license to display the preprint in perpetuity.

It is made available under a CC-BY-NC-ND 4.0 International license .

We acknowledge the help and support of our Information Scientist, Deirdre Andre (DA), University of Leeds. We also acknowledge the support of Eleanor Grant (EG) and Andre Etchebarne $(\mathrm{AE})$ in categorising the interventions and data extraction. We also thank $\mathrm{Dr}$ Mark Perry for his contributions to the design of this review.

This report presents independent research funded by the National Institute for Health Research (NIHR) under its Programme Grants for Applied Research Programme, (Development and evaluation of strategies to reduce sedentary behaviour in patients after stroke and improve outcomes, RP-PG-0615-20019).

The views expressed in this publication are those of the author(s) and not necessarily those of the NIHR or the Department of Health and Social Care.

\section{References}

1. Tremblay MS, Aubert S, Barnes JD, Saunders TJ, Carson V, Latimer-Cheung AE, et al. Sedentary Behavior Research Network (SBRN) - Terminology Consensus Project process and outcome. Int J Behav Nutr Phys Act. 2017;14(1):75.

2. Healy GN, Dunstan DW, Salmon J, Cerin E, Shaw JE, Zimmet PZ, et al. Breaks in sedentary time: beneficial associations with metabolic risk. Diabetes Care. 2008;31(4):661-6.

3. Owen N, Healy GN, Matthews CE, Dunstan DW. Too much sitting: the population health science of sedentary behavior. Exerc Sport Sci Rev. 2010;38(3):105-13.

4. de Rezende LF, Rey-Lopez JP, Matsudo VK, do Carmo Luiz O. Sedentary behavior and health outcomes among older adults: a systematic review. BMC Public Health. 2014;14:333.

5. Heron L, O'Neill C, McAneney H, Kee F, Tully MA. Direct healthcare costs of sedentary behaviour in the UK. J Epidemiol Community Health. 2019;73(7):625-9.

6. Saunders TJ, Mclsaac T, Douillette K, Gaulton N, Hunter S, Rhodes RE, et al. Sedentary behaviour and health in adults: an overview of systematic reviews. Appl Physiol Nutr Metab. 2020;45(10 (Suppl. 2)):S197-s217.

7. Teychenne M, Stephens LD, Costigan SA, Olstad DL, Stubbs B, Turner AI. The association between sedentary behaviour and indicators of stress: a systematic review. BMC public health. 2019;19(1):1357-.

8. Santos DA, Silva AM, Baptista F, Santos R, Vale S, Mota J, et al. Sedentary behavior and physical activity are independently related to functional fitness in older adults. Exp Gerontol. 2012;47(12):908-12. 
medRxiv preprint doi: https://doi.org/10.1101/2021.05.27.21256673; this version posted May 29, 2021. The copyright holder for this preprint

(which was not certified by peer review) is the author/funder, who has granted medRxiv a license to display the preprint in perpetuity.

It is made available under a CC-BY-NC-ND 4.0 International license .

9. Gennuso KP, Gangnon RE, Matthews CE, Thraen-Borowski KM, Colbert LH. Sedentary behavior, physical activity, and markers of health in older adults. Med Sci Sports Exerc. 2013;45(8):1493-500.

10. Teychenne M, Ball K, Salmon J. Sedentary behavior and depression among adults: a review. Int J Behav Med. 2010;17(4):246-54.

11. Teychenne M, Costigan SA, Parker K. The association between sedentary behaviour and risk of anxiety: a systematic review. BMC Public Health. 2015;15:513.

12. Edwardson CL, Gorely T, Davies MJ, Gray LJ, Khunti K, Wilmot EG, et al. Association of sedentary behaviour with metabolic syndrome: a meta-analysis. PLoS One. 2012;7(4):e34916.

13. Same RV, Feldman DI, Shah N, Martin SS, AI Rifai M, Blaha MJ, et al. Relationship Between Sedentary Behavior and Cardiovascular Risk. Curr Cardiol Rep. 2016;18(1):6.

14. Katzmarzyk PT, Church TS, Craig CL, Bouchard C. Sitting time and mortality from all causes, cardiovascular disease, and cancer. Med Sci Sports Exerc. 2009;41(5):998-1005.

15. Matthews CE, George SM, Moore SC, Bowles HR, Blair A, Park Y, et al. Amount of time spent in sedentary behaviors and cause-specific mortality in US adults. The American journal of clinical nutrition. 2012;95(2):437-45.

16. Seguin R, Buchner DM, Liu J, Allison M, Manini T, Wang CY, et al. Sedentary behavior and mortality in older women: the Women's Health Initiative. Am J Prev Med. 2014;46(2):122-35.

17. van der Ploeg HP, Chey T, Korda RJ, Banks E, Bauman A. Sitting time and all-cause mortality risk in 222497 Australian adults. Arch Intern Med. 2012;172(6):494-500.

18. Bauman AE, Petersen CB, Blond K, Rangul V, Hardy LL. The Descriptive Epidemiology of Sedentary Behaviour. In: Leitzmann MF, Jochem C, Schmid D, editors. Sedentary Behaviour Epidemiology. Cham: Springer International Publishing; 2018. p. 73106.

19. Dunstan DW, Howard B, Healy GN, Owen N. Too much sitting--a health hazard. Diabetes Res Clin Pract. 2012;97(3):368-76.

20. Biswas A, Oh PI, Faulkner GE, Bajaj RR, Silver MA, Mitchell MS, et al. Sedentary time and its association with risk for disease incidence, mortality, and hospitalization in adults: a systematic review and meta-analysis. Ann Intern Med. 2015;162(2):123-32.

21. Ekelund U, Steene-Johannessen J, Brown WJ, Fagerland MW, Owen N, Powell KE, et al. Does physical activity attenuate, or even eliminate, the detrimental association of sitting time with mortality? A harmonised meta-analysis of data from more than 1 million men and women. Lancet. 2016;388(10051):1302-10.

22. Guthold R, Stevens GA, Riley LM, Bull FC. Worldwide trends in insufficient physical activity from 2001 to 2016: a pooled analysis of 358 population-based surveys with 1.9 million participants. Lancet Glob Health. 2018;6(10):e1077-e86.

23. Prince SA, Saunders TJ, Gresty K, Reid RD. A comparison of the effectiveness of physical activity and sedentary behaviour interventions in reducing sedentary time in adults: a systematic review and meta-analysis of controlled trials. Obes Rev. 2014;15(11):905-19. 
medRxiv preprint doi: https://doi.org/10.1101/2021.05.27.21256673; this version posted May 29, 2021. The copyright holder for this preprint (which was not certified by peer review) is the author/funder, who has granted medRxiv a license to display the preprint in perpetuity. It is made available under a CC-BY-NC-ND 4.0 International license .

24. Martin A, Fitzsimons C, Jepson R, Saunders DH, van der Ploeg HP, Teixeira PJ, et al. Interventions with potential to reduce sedentary time in adults: systematic review and meta-analysis. Br J Sports Med. 2015;49(16):1056-63.

25. Gardner B, Smith L, Lorencatto F, Hamer M, Biddle SJ. How to reduce sitting time? A review of behaviour change strategies used in sedentary behaviour reduction interventions among adults. Health Psychol Rev. 2016;10(1):89-112.

26. Shrestha N, Kukkonen-Harjula KT, Verbeek JH, ljaz S, Hermans V, Bhaumik S. Workplace interventions for reducing sitting at work. Cochrane Database of Systematic Reviews. 2016(3).

27. Thraen-Borowski KM, Ellingson LD, Meyer JD, Cadmus-Bertram L. Nonworksite Interventions to Reduce Sedentary Behavior among Adults: A Systematic Review. Transl J Am Coll Sports Med. 2017;2(12):68-78.

28. Shrestha N, Grgic J, Wiesner G, Parker A, Podnar H, Bennie JA, et al. Effectiveness of interventions for reducing non-occupational sedentary behaviour in adults and older adults: a systematic review and meta-analysis. Br J Sports Med. 2018.

29. Blackburn NE, Wilson JJ, McMullan, II, Caserotti P, Gine-Garriga M, Wirth K, et al. The effectiveness and complexity of interventions targeting sedentary behaviour across the lifespan: a systematic review and meta-analysis. Int J Behav Nutr Phys Act. 2020;17(1):53.

30. Peachey MM, Richardson J, V Tang A, Dal-Bello Haas V, Gravesande J.

Environmental, behavioural and multicomponent interventions to reduce adults\&\#039; sitting time: a systematic review and meta-analysis. British Journal of Sports Medicine. 2018.

31. Roy-O'Reilly M, McCullough LD. Age and Sex Are Critical Factors in Ischemic Stroke Pathology. Endocrinology. 2018;159(8):3120-31.

32. Moher D, Liberati A, Tetzlaff J, Altman DG, Group P. Preferred reporting items for systematic reviews and meta-analyses: the PRISMA statement. Bmj. 2009;339:b2535.

33. Craig CL, Marshall AL, Sjostrom M, Bauman AE, Booth ML, Ainsworth BE, et al. International physical activity questionnaire: 12 -country reliability and validity. Med Sci Sports Exerc. 2003;35(8):1381-95.

34. Marshall AL, Miller YD, Burton NW, Brown WJ. Measuring total and domain-specific sitting: a study of reliability and validity. Med Sci Sports Exerc. 2010;42(6):1094-102.

35. Higgins J, Green S. Cochrane handbook for systematic reviews of interventions Version 5.1.0.201123 February 2018. Available from: http://handbook-5-1.cochrane.org/.

36. GRADEpro G. GRADEpro GDT: GRADEpro Guideline Development Tool [Software]. McMaster University, 2015 (developed by Evidence Prime, Inc.). 2015.

37. Guyatt G, Oxman AD, Akl EA, Kunz R, Vist G, Brozek J, et al. GRADE guidelines: 1. Introduction-GRADE evidence profiles and summary of findings tables. J Clin Epidemiol. 2011;64(4):383-94.

38. Higgins JPT, Eldridge S, Li T (editors). Chapter 23: Including variants on randomized trials. In: Higgins JPT, Thomas J, Chandler J, Cumpston M, Li T, Page MJ, et al., editors. Cochrane Handbook for Systematic Reviews of Interventions. version 6.2 (updated February 2021) ed: Cochrane; 2021. Available from www.training.cochrane.org/handbook. 
medRxiv preprint doi: https://doi.org/10.1101/2021.05.27.21256673; this version posted May 29, 2021. The copyright holder for this preprint (which was not certified by peer review) is the author/funder, who has granted medRxiv a license to display the preprint in perpetuity. It is made available under a CC-BY-NC-ND 4.0 International license .

39. Abascal LB. The effect of depression and adherence in a dietary and physical activity intervention for overweight and obese adults. San Diego: University of California, San Diego and San Diego State University; 2008.

40. Raynor HA, Steeves EA, Bassett DR, Jr., Thompson DL, Gorin AA, Bond DS. Reducing TV watching during adult obesity treatment: two pilot randomized controlled trials. Behav Ther. 2013;44(4):674-85.

41. Aadahl M, Linneberg A, Moller TC, Rosenorn S, Dunstan DW, Witte DR, et al. Motivational counseling to reduce sitting time: a community-based randomized controlled trial in adults. Am J Prev Med. 2014;47(5):576-86.

42. Ashe MC, Winters M, Hoppmann CA, Dawes MG, Gardiner PA, Giangregorio LM, et al. "Not just another walking program": Everyday Activity Supports You (EASY) model-a randomized pilot study for a parallel randomized controlled trial. Pilot Feasibility Stud. 2015;1:4.

43. Baker G, Gray SR, Wright A, Fitzsimons C, Nimmo M, Lowry R, et al. The effect of a pedometer-based community walking intervention "Walking for Wellbeing in the West" on physical activity levels and health outcomes: a 12-week randomized controlled trial. Int $\mathrm{J}$ Behav Nutr Phys Act. 2008;5:44.

44. Balducci S, D'Errico V, Haxhi J, Sacchetti M, Orlando G, Cardelli P, et al. Effect of a Behavioral Intervention Strategy for Adoption and Maintenance of a Physically Active Lifestyle: The Italian Diabetes and Exercise Study 2 (IDES_2): A Randomized Controlled Trial. Diabetes Care. 2017;40(11):1444-52.

45. Barone Gibbs B, Brach JS, Byard T, Creasy S, Davis KK, McCoy S, et al. Reducing Sedentary Behavior Versus Increasing Moderate-to-Vigorous Intensity Physical Activity in Older Adults. J Aging Health. 2017;29(2):247-67.

46. Barwais FA, Cuddihy TF, Tomson LM. Physical activity, sedentary behavior and total wellness changes among sedentary adults: a 4-week randomized controlled trial. Health Qual Life Outcomes. 2013;11:183.

47. Biddle SJ, Edwardson CL, Wilmot EG, Yates T, Gorely T, Bodicoat DH, et al. A Randomised Controlled Trial to Reduce Sedentary Time in Young Adults at Risk of Type 2 Diabetes Mellitus: Project STAND (Sedentary Time ANd Diabetes). PLoS One. 2015;10(12):e0143398.

48. Breyer MK, Breyer-Kohansal R, Funk GC, Dornhofer N, Spruit MA, Wouters EF, et al. Nordic walking improves daily physical activities in COPD: a randomised controlled trial. Respir Res. 2010;11:112.

49. Burke L, Lee AH, Jancey J, Xiang L, Kerr DA, Howat PA, et al. Physical activity and nutrition behavioural outcomes of a home-based intervention program for seniors: a randomized controlled trial. Int J Behav Nutr Phys Act. 2013;10:14.

50. Carlson JA, Sallis JF, Ramirez ER, Patrick K, Norman GJ. Physical activity and dietary behavior change in Internet-based weight loss interventions: comparing two multiplebehavior change indices. Prev Med. 2012;54(1):50-4.

51. Chin A Paw MJ, van Poppel MN, van Mechelen W. Effects of resistance and functional-skills training on habitual activity and constipation among older adults living in long-term care facilities: a randomized controlled trial. BMC Geriatrics. 2006;6(1):9. 
medRxiv preprint doi: https://doi.org/10.1101/2021.05.27.21256673; this version posted May 29, 2021. The copyright holder for this preprint (which was not certified by peer review) is the author/funder, who has granted medRxiv a license to display the preprint in perpetuity. It is made available under a CC-BY-NC-ND 4.0 International license .

52. Cooper AJ, Brage S, Ekelund U, Wareham NJ, Griffin SJ, Simmons RK. Association between objectively assessed sedentary time and physical activity with metabolic risk factors among people with recently diagnosed type 2 diabetes. Diabetologia. 2014;57(1):73-82.

53. Cotten E, Prapavessis H. Increasing Nonsedentary Behaviors in University Students Using Text Messages: Randomized Controlled Trial. JMIR Mhealth Uhealth. 2016;4(3):e99.

54. Cruz J, Brooks D, Marques A. Walk2Bactive: A randomised controlled trial of a physical activity-focused behavioural intervention beyond pulmonary rehabilitation in chronic obstructive pulmonary disease. Chron Respir Dis. 2016;13(1):57-66.

55. De Cocker K, Spittaels H, Cardon G, De Bourdeaudhuij I, Vandelanotte C. Webbased, computer-tailored, pedometer-based physical activity advice: development, dissemination through general practice, acceptability, and preliminary efficacy in a randomized controlled trial. J Med Internet Res. 2012;14(2):e53.

56. De Greef K, Deforche B, Tudor-Locke C, De Bourdeaudhuij I. A cognitivebehavioural pedometer-based group intervention on physical activity and sedentary behaviour in individuals with type 2 diabetes. Health Educ Res. 2010;25(5):724-36.

57. De Greef KP, Deforche BI, Ruige JB, Bouckaert JJ, Tudor-Locke CE, Kaufman JM, et al. The effects of a pedometer-based behavioral modification program with telephone support on physical activity and sedentary behavior in type 2 diabetes patients. Patient Educ Couns. 2011;84(2):275-9.

58. de Roon M, van Gemert WA, Peeters PH, Schuit AJ, Monninkhof EM. Long-term effects of a weight loss intervention with or without exercise component in postmenopausal women: A randomized trial. Prev Med Rep. 2017;5:118-23.

59. Dunn A, Marcus B, Kampert J, Garcia M, Kohl 3rd H, Blair S. Comparison of lifestyle and structured interventions to increase physical activity and cardiorespiratory fitness: a randomized trial. JAMA. 1999;281(4):327.

60. Ellingson LD, Meyer JD, Cook DB. Wearable technology reduces prolonged bouts of sedentary behavior. Translational Journal of the American College of Sports Medicine. 2016;1(2):10-7.

61. English C, Healy GN, Olds T, Parfitt G, Borkoles E, Coates A, et al. Reducing Sitting Time After Stroke: A Phase II Safety and Feasibility Randomized Controlled Trial. Arch Phys Med Rehabil. 2016;97(2):273-80.

62. Fanning J, Porter G, Awick EA, Wojcicki TR, Gothe NP, Roberts SA, et al. Effects of a DVD-delivered exercise program on patterns of sedentary behavior in older adults: a randomized controlled trial. Prev Med Rep. 2016;3:238-43.

63. Fitzgibbon M, Stolley M, Schiffer L, Sanchez-Johnsen L, Wells A, Dyer A. A combined breast health/weight loss intervention for Black women. Preventive medicine. 2005;40(4):373.

64. Gomersall S, Maher C, English C, Rowlands A, Olds T. Time regained: when people stop a physical activity program, how does their time use change? A randomised controlled trial. PLoS One. 2015;10(5):e0126665.

65. Hansen AW, Gronbaek M, Helge JW, Severin M, Curtis T, Tolstrup JS. Effect of a Web-based intervention to promote physical activity and improve health among physically 
medRxiv preprint doi: https://doi.org/10.1101/2021.05.27.21256673; this version posted May 29, 2021. The copyright holder for this preprint (which was not certified by peer review) is the author/funder, who has granted medRxiv a license to display the preprint in perpetuity. It is made available under a CC-BY-NC-ND 4.0 International license .

inactive adults: a population-based randomized controlled trial. J Med Internet Res. 2012;14(5):e145.

66. Harris T, Kerry SM, Limb ES, Victor CR, lliffe S, Ussher M, et al. Effect of a Primary Care Walking Intervention with and without Nurse Support on Physical Activity Levels in 45to 75-Year-Olds: The Pedometer And Consultation Evaluation (PACE-UP) Cluster Randomised Clinical Trial. PLoS Med. 2017;14(1):e1002210.

67. Helgadóttir B, Owen N, Dunstan DW, Ekblom Ö, Hallgren M, Forsell Y. Changes in physical activity and sedentary behavior associated with an exercise intervention in depressed adults. Psychology of Sport and Exercise. 2017;30:10-8.

68. Hawkins M, Chasan-Taber L, Marcus B, Stanek E, Braun B, Ciccolo J, et al. Impact of an exercise intervention on physical activity during pregnancy: the behaviors affecting baby and you study. Am J Public Health. 2014;104(10):e74-81.

69. Herring LY, Stevinson C, Carter P, Biddle SJH, Bowrey D, Sutton C, et al. The effects of supervised exercise training 12-24 months after bariatric surgery on physical function and body composition: a randomised controlled trial. Int $\mathrm{J}$ Obes (Lond). 2017;41(6):909-16.

70. Hu G, Tian H, Zhang F, Liu H, Zhang C, Zhang S, et al. Tianjin Gestational Diabetes Mellitus Prevention Program: study design, methods, and 1-year interim report on the feasibility of lifestyle intervention program. Diabetes Res Clin Pract. 2012;98(3):508-17.

71. Huberty JL, Buman MP, Leiferman JA, Bushar J, Hekler EB, Adams MA. Dose and timing of text messages for increasing physical activity among pregnant women: a randomized controlled trial. Transl Behav Med. 2017;7(2):212-23.

72. James EL, Stacey FG, Chapman K, Boyes AW, Burrows T, Girgis A, et al. Impact of a nutrition and physical activity intervention (ENRICH: Exercise and Nutrition Routine Improving Cancer Health) on health behaviors of cancer survivors and carers: a pragmatic randomized controlled trial. BMC Cancer. 2015;15:710.

73. Jauho AM, Pyky R, Ahola R, Kangas M, Virtanen P, Korpelainen R, et al. Effect of wrist-worn activity monitor feedback on physical activity behavior: A randomized controlled trial in Finnish young men. Prev Med Rep. 2015;2:628-34.

74. Joseph RP, Keller C, Adams MA, Ainsworth BE. Print versus a culturally-relevant Facebook and text message delivered intervention to promote physical activity in African American women: a randomized pilot trial. BMC Womens Health. 2015;15:30.

75. Kallings LV, Sierra Johnson J, Fisher RM, Faire U, Stahle A, Hemmingsson E, et al. Beneficial effects of individualized physical activity on prescription on body composition and cardiometabolic risk factors: results from a randomized controlled trial. Eur J Cardiovasc Prev Rehabil. 2009;16(1):80-4.

76. Katzmarzyk PT, Champagne CM, Tudor-Locke C, Broyles ST, Harsha D, Kennedy $\mathrm{BM}$, et al. A short-term physical activity randomized trial in the Lower Mississippi Delta. PLoS One. 2011;6(10):e26667.

77. King AC, Hekler EB, Grieco LA, Winter SJ, Sheats JL, Buman MP, et al. Effects of Three Motivationally Targeted Mobile Device Applications on Initial Physical Activity and Sedentary Behavior Change in Midlife and Older Adults: A Randomized Trial. PLoS One. 2016;11(6):e0156370. 
medRxiv preprint doi: https://doi.org/10.1101/2021.05.27.21256673; this version posted May 29, 2021. The copyright holder for this preprint (which was not certified by peer review) is the author/funder, who has granted medRxiv a license to display the preprint in perpetuity. It is made available under a CC-BY-NC-ND 4.0 International license .

78. Lakerveld J, Bot SD, van der Ploeg HP, Nijpels G. The effects of a lifestyle intervention on leisure-time sedentary behaviors in adults at risk: the Hoorn Prevention Study, a randomized controlled trial. Prev Med. 2013;57(4):351-6.

79. Lane A, Murphy N, Bauman A, Chey T. Randomized controlled trial to increase physical activity among insufficiently active women following their participation in a mass event. Health education journal. 2010;69(3):287-96.

80. Li LC, Sayre EC, Xie H, Clayton C, Feehan LM. A Community-Based Physical Activity Counselling Program for People With Knee Osteoarthritis: Feasibility and Preliminary Efficacy of the Track-OA Study. JMIR Mhealth Uhealth. 2017;5(6):e86.

81. Reduction of Sitting Time: Sedentarism Intervention Trial. ClinicalTrials.gov; 2015.

82. Lopez-Fontana CM, Sanchez-Villegas A, Martinez-Gonzalez MA, Martinez JA. Daily physical activity and macronutrient distribution of low-calorie diets jointly affect body fat reduction in obese women. Appl Physiol Nutr Metab. 2009;34(4):595-602.

83. Lyons EJ, Swartz MC, Lewis ZH, Martinez E, Jennings K. Feasibility and Acceptability of a Wearable Technology Physical Activity Intervention With Telephone Counseling for Mid-Aged and Older Adults: A Randomized Controlled Pilot Trial. JMIR Mhealth Uhealth. 2017;5(3):e28.

84. McAuley E, Wojcicki TR, Learmonth YC, Roberts SA, Hubbard EA, Kinnett-Hopkins $D$, et al. Effects of a DVD-delivered exercise intervention on physical function in older adults with multiple sclerosis: A pilot randomized controlled trial. Mult Scler J Exp Transl Clin. 2015;1:2055217315584838.

85. McGuire M, Jeffery R, French S, Hannan P. The relationship between restraint and weight and weight-related behaviors among individuals in a community weight gain prevention trial. International journal of obesity and related metabolic disorders: journal of the International Association for the Study of Obesity. $2001 ; 25(4): 574$.

86. Miyamoto T, Fukuda K, Oshima Y, Moritani T. Non-locomotive physical activity intervention using a tri-axial accelerometer reduces sedentary time in type 2 diabetes. Phys Sportsmed. 2017;45(3):245-51.

87. Morgan PJ, Callister R, Collins CE, Plotnikoff RC, Young MD, Berry N, et al. The SHED-IT community trial: a randomized controlled trial of internet- and paper-based weight loss programs tailored for overweight and obese men. Ann Behav Med. 2013;45(2):139-52.

88. Muller AM, Khoo S, Morris T. Text Messaging for Exercise Promotion in Older Adults From an Upper-Middle-Income Country: Randomized Controlled Trial. J Med Internet Res. 2016;18(1):e5.

89. Mutrie N, Doolin O, Fitzsimons CF, Grant PM, Granat M, Grealy M, et al. Increasing older adults' walking through primary care: results of a pilot randomized controlled trial. Fam Pract. 2012;29(6):633-42.

90. Noites A, Pinto J, Freitas CP, Melo C, Albuquerque A, Teixeira M, et al. Effects of microcurrents and physical exercise on the abdominal fat in patients with coronary artery disease. European Journal of Integrative Medicine. 2015;7(5):499-507. 
medRxiv preprint doi: https://doi.org/10.1101/2021.05.27.21256673; this version posted May 29, 2021. The copyright holder for this preprint (which was not certified by peer review) is the author/funder, who has granted medRxiv a license to display the preprint in perpetuity. It is made available under a CC-BY-NC-ND 4.0 International license .

91. O'Halloran PD, Shields N, Blackstock F, Wintle E, Taylor NF. Motivational interviewing increases physical activity and self-efficacy in people living in the community after hip fracture: a randomized controlled trial. Clin Rehabil. 2016;30(11):1108-19.

92. Otten JJ, Jones KE, Littenberg B, Harvey-Berino J. Effects of television viewing reduction on energy intake and expenditure in overweight and obese adults: a randomized controlled trial. Arch Intern Med. 2009;169(22):2109-15.

93. Ostbye T, Krause KM, Lovelady CA, Morey MC, Bastian LA, Peterson BL, et al. Active Mothers Postpartum: a randomized controlled weight-loss intervention trial. Am J Prev Med. 2009;37(3):173-80.

94. Overgaard K, Nannerup K, Lunen MKB, Maindal HT, Larsen RG. Exercise more or sit less? A randomized trial assessing the feasibility of two advice-based interventions in obese inactive adults. J Sci Med Sport. 2018;21(7):708-13.

95. Pyky R, Koivumaa-Honkanen H, Leinonen A-M, Ahola R, Hirvonen N, Enwald H, et al. Effect of tailored, gamified, mobile physical activity intervention on life satisfaction and self-rated health in young adolescent men: a population-based, randomized controlled trial (MOPO study). Computers in Human Behavior. 2017;72:13-22.

96. Papalazarou A, Yannakoulia M, Kavouras SA, Komesidou V, Dimitriadis G, Papakonstantinou $A$, et al. Lifestyle intervention favorably affects weight loss and maintenance following obesity surgery. Obesity (Silver Spring). 2010;18(7):1348-53.

97. Petersen CB, Severin M, Hansen AW, Curtis T, Gronbaek M, Tolstrup JS. A population-based randomized controlled trial of the effect of combining a pedometer with an intervention toolkit on physical activity among individuals with low levels of physical activity or fitness. Prev Med. 2012;54(2):125-30.

98. Pinto B, Dunsiger S, Stein K. Does a peer-led exercise intervention affect sedentary behavior among breast cancer survivors? Psychooncology. 2017;26(11):1907-13.

99. Poston L, Briley AL, Barr S, Bell R, Croker H, Coxon K, et al. Developing a complex intervention for diet and activity behaviour change in obese pregnant women (the UPBEAT trial); assessment of behavioural change and process evaluation in a pilot randomised controlled trial. BMC Pregnancy Childbirth. 2013;13:148.

100. Recio-Rodriguez Jl, Agudo-Conde C, Martin-Cantera C, Gonzalez-Viejo MN, Fernandez-Alonso MD, Arietaleanizbeaskoa MS, et al. Short-Term Effectiveness of a Mobile Phone App for Increasing Physical Activity and Adherence to the Mediterranean Diet in Primary Care: A Randomized Controlled Trial (EVIDENT II Study). J Med Internet Res. 2016;18(12):e331.

101. Rockette-Wagner B, Edelstein S, Venditti EM, Reddy D, Bray GA, Carrion-Petersen $\mathrm{ML}$, et al. The impact of lifestyle intervention on sedentary time in individuals at high risk of diabetes. Diabetologia. 2015;58(6):1198-202.

102. Sazlina SG, Browning CJ, Yasin S. Effectiveness of Personalized Feedback Alone or Combined with Peer Support to Improve Physical Activity in Sedentary Older Malays with Type 2 Diabetes: A Randomized Controlled Trial. Front Public Health. 2015;3:178.

103. Serrano-Guzman M, Aguilar-Ferrandiz ME, Valenza CM, Ocana-Peinado FM, Valenza-Demet G, Villaverde-Gutierrez C. Effectiveness of a flamenco and sevillanas program to enhance mobility, balance, physical activity, blood pressure, body mass, and 
medRxiv preprint doi: https://doi.org/10.1101/2021.05.27.21256673; this version posted May 29, 2021. The copyright holder for this preprint

(which was not certified by peer review) is the author/funder, who has granted medRxiv a license to display the preprint in perpetuity.

It is made available under a CC-BY-NC-ND 4.0 International license .

quality of life in postmenopausal women living in the community in Spain: a randomized clinical trial. Menopause. 2016;23(9):965-73.

104. Short CE, James EL, Girgis A, D'Souza MI, Plotnikoff RC. Main outcomes of the Move More for Life Trial: a randomised controlled trial examining the effects of tailored-print and targeted-print materials for promoting physical activity among post-treatment breast cancer survivors. Psychooncology. 2015;24(7):771-8.

105. Slootmaker SM, Chinapaw MJ, Schuit AJ, Seidell JC, Van Mechelen W. Feasibility and effectiveness of online physical activity advice based on a personal activity monitor: randomized controlled trial. J Med Internet Res. 2009;11(3):e27.

106. Spring B, Schneider K, McFadden HG, Vaughn J, Kozak AT, Smith M, et al. Multiple behavior changes in diet and activity: a randomized controlled trial using mobile technology. Arch Intern Med. 2012;172(10):789-96.

107. Steeves JA, Bassett DR, Fitzhugh EC, Raynor HA, Thompson DL. Can sedentary behavior be made more active? A randomized pilot study of TV commercial stepping versus walking. Int J Behav Nutr Phys Act. 2012;9:95.

108. Suboc TB, Strath SJ, Dharmashankar K, Coulliard A, Miller N, Wang J, et al. Relative importance of step count, intensity, and duration on physical activity's impact on vascular structure and function in previously sedentary older adults. J Am Heart Assoc.

2014;3(1):e000702.

109. Thompson JL, Allen P, Helitzer DL, Qualls C, Whyte AN, Wolfe VK, et al. Reducing diabetes risk in American Indian women. Am J Prev Med. 2008;34(3):192-201.

110. Thomsen T, Aadahl M, Beyer N, Hetland ML, Loppenthin K, Midtgaard J, et al. Motivational counselling and SMS-reminders for reduction of daily sitting time in patients with rheumatoid arthritis: a descriptive randomised controlled feasibility study. BMC Musculoskelet Disord. 2016;17(1):434.

111. Thomsen T, Aadahl M, Beyer N, Hetland ML, Loppenthin K, Midtgaard J, et al. The efficacy of motivational counselling and SMS reminders on daily sitting time in patients with rheumatoid arthritis: a randomised controlled trial. Ann Rheum Dis. 2017;76(9):1603-6.

112. White I, Smith L, Aggio D, Shankar S, Begum S, Matei R, et al. On Your Feet to Earn Your Seat: pilot RCT of a theory-based sedentary behaviour reduction intervention for older adults. Pilot Feasibility Stud. 2017;3:23.

113. Wootton SL, Hill K, Alison JA, Ng LWC, Jenkins S, Eastwood PR, et al. Effects of ground-based walking training on daily physical activity in people with COPD: A randomised controlled trial. Respir Med. 2017;132:139-45.

114. Andersen E, Burton NW, Anderssen SA. Physical activity levels six months after a randomised controlled physical activity intervention for Pakistani immigrant men living in Norway. Int J Behav Nutr Phys Act. 2012;9:47.

115. Albright CL, Steffen AD, Wilkens LR, White KK, Novotny R, Nigg CR, et al. Effectiveness of a 12-month randomized clinical trial to increase physical activity in multiethnic postpartum women: results from Hawaii's Nā Mikimiki Project. Prev Med. 2014;69:214-23. 
medRxiv preprint doi: https://doi.org/10.1101/2021.05.27.21256673; this version posted May 29, 2021. The copyright holder for this preprint (which was not certified by peer review) is the author/funder, who has granted medRxiv a license to display the preprint in perpetuity. It is made available under a CC-BY-NC-ND 4.0 International license .

116. Spittaels H, De Bourdeaudhuij I, Brug J, Vandelanotte C. Effectiveness of an online computer-tailored physical activity intervention in a real-life setting. Health Educ Res. 2007;22(3):385-96.

117. Adams MM, Gill DL. Reducing Sedentary Behavior: Active Steps for Overweight Women. Women in Sport and Physical Activity Journal. 2015;23(1):9-18.

118. Lioret S, Campbell KJ, Crawford D, Spence AC, Hesketh K, McNaughton SA. A parent focused child obesity prevention intervention improves some mother obesity risk behaviors: the Melbourne inFANT program. Int J Behav Nutr Phys Act. 2012;9:100.

119. Maher JP, Sliwinski MJ, Conroy DE. Feasibility and preliminary efficacy of an intervention to reduce older adults' sedentary behavior. Transl Behav Med. 2017;7(1):52-61.

120. Berendsen BAJ, Hendriks MRC, Krenmers SPJ, Schaper NC, Savelberg HHCM. Amount of guidance in a combined lifestyle intervention to improve lifestyle of overweight people: the more, the better? European Journal of Epidemiology. 2015;30:792.

121. Melville CA, Mitchell F, Stalker K, Matthews L, McConnachie A, Murray HM, et al. Effectiveness of a walking programme to support adults with intellectual disabilities to increase physical activity: walk well cluster-randomised controlled trial. Int J Behav Nutr Phys Act. 2015;12:125.

122. Noites A, Freitas CP, Pinto J, Melo C, Vieira A, Albuquerque A, et al. Effects of a Phase IV Home-Based Cardiac Rehabilitation Program on Cardiorespiratory Fitness and Physical Activity. Heart Lung Circ. 2017;26(5):455-62.

123. Dipietro L, Caspersen CJ, Ostfeld AM, Nadel ER. A survey for assessing physical activity among older adults. Med Sci Sports Exerc. 1993;25(5):628-42.

124. Pettee Gabriel K, McClain JJ, Schmid KK, Storti KL, Ainsworth BE. Reliability and convergent validity of the past-week Modifiable Activity Questionnaire. Public health nutrition. 2011;14(3):435-42.

125. Kollia M, Kavouras SA, Gioxari A, Maraki M, Sidossis LS. Development, validity and reliability of the Harokopio Physical Activity Questionnaire in Greek adults. 8th Panhellenic Congress on Nutrition and Dietetics. Athens2006. p. 130-1.

126. Barwais FA, Cuddihy TF, Washington T, Tomson LM, Brymer E. Development and validation of a new self-report instrument for measuring sedentary behaviors and lightintensity physical activity in adults. Journal of physical activity \& health. 2014;11(6):1097104.

127. Buman MP, Winkler EA, Kurka JM, Hekler EB, Baldwin CM, Owen N, et al. Reallocating time to sleep, sedentary behaviors, or active behaviors: associations with cardiovascular disease risk biomarkers, NHANES 2005-2006. Am J Epidemiol. 2014;179(3):323-34.

128. Grgic J, Dumuid D, Bengoechea EG, Shrestha N, Bauman A, Olds T, et al. Health outcomes associated with reallocations of time between sleep, sedentary behaviour, and physical activity: a systematic scoping review of isotemporal substitution studies. Int J Behav Nutr Phys Act. 2018;15(1):69. 
medRxiv preprint doi: https://doi.org/10.1101/2021.05.27.21256673; this version posted May 29, 2021. The copyright holder for this preprint (which was not certified by peer review) is the author/funder, who has granted medRxiv a license to display the preprint in perpetuity. It is made available under a CC-BY-NC-ND 4.0 International license .

129. Yates T, Henson J, Edwardson C, Dunstan D, Bodicoat DH, Khunti K, et al. Objectively measured sedentary time and associations with insulin sensitivity: Importance of reallocating sedentary time to physical activity. Prev Med. 2015;76:79-83.

130. Del Pozo-Cruz J, Garcia-Hermoso A, Alfonso-Rosa RM, Alvarez-Barbosa F, Owen N, Chastin S, et al. Replacing Sedentary Time: Meta-analysis of Objective-Assessment Studies. Am J Prev Med. 2018;55(3):395-402.

131. Zabatiero J, Ng L, Clayton R, Middlemiss S, Kang K, Harrold M, et al. Effectiveness of interventions aiming at reducing sedentary behaviour in a non-surgical population with overweight or obesity: A systematic review and meta-analysis. Obes Res Clin Pract. 2019;13(2):115-28.

132. Prince SA, Butler GP, Rao DP, Thompson W. Evidence synthesis - Where are children and adults physically active and sedentary? - a rapid review of location-based studies. Health Promot Chronic Dis Prev Can. 2019;39(3):67-103.

133. Cleland V, Squibb K, Stephens L, Dalby J, Timperio A, Winzenberg T, et al. Effectiveness of interventions to promote physical activity and/or decrease sedentary behaviour among rural adults: a systematic review and meta-analysis. Obes Rev. 2017; 18(7):727-41.

134. Langoien LJ, Terragni L, Rugseth G, Nicolaou M, Holdsworth M, Stronks K, et al. Systematic mapping review of the factors influencing physical activity and sedentary behaviour in ethnic minority groups in Europe: a DEDIPAC study. Int J Behav Nutr Phys Act. 2017;14(1):99.

135. Palmer VJ, Gray CM, Fitzsimons CF, Mutrie N, Wyke S, Deary IJ, et al. What Do Older People Do When Sitting and Why? Implications for Decreasing Sedentary Behavior. Gerontologist. 2019;59(4):686-97.

136. Hoffmann TC, Glasziou PP, Boutron I, Milne R, Perera R, Moher D, et al. Better reporting of interventions: template for intervention description and replication (TIDieR) checklist and guide. Bmj. 2014;348:g1687.

137. Prince SA, LeBlanc AG, Colley RC, Saunders TJ. Measurement of sedentary behaviour in population health surveys: a review and recommendations. PeerJ. 2017;5:e4130.

138. Stamatakis E, Ekelund U, Ding D, Hamer M, Bauman AE, Lee IM. Is the time right for quantitative public health guidelines on sitting? A narrative review of sedentary behaviour research paradigms and findings. Br J Sports Med. 2019;53(6):377-82.

139. Moore GF, Audrey S, Barker M, Bond L, Bonell C, Hardeman W, et al. Process evaluation of complex interventions: Medical Research Council guidance. Bmj. 2015;350:h1258.

\section{Supporting Information}


medRxiv preprint doi: https://doi.org/10.1101/2021.05.27.21256673; this version posted May 29, 2021. The copyright holder for this preprint (which was not certified by peer review) is the author/funder, who has granted medRxiv a license to display the preprint in perpetuity. It is made available under a CC-BY-NC-ND 4.0 International license .

Additional file 1: PRISMA checklist (DOC)

Additional file 2: MEDLINE search strategy (DOC)

Additional file 3: Table of characteristics for included studies (DOC)

Additional file 4: GRADE assessment (DOC) 